\title{
Pharmacophagy and pharmacophory: mechanisms of self-medication and disease prevention in the honeybee colony (Apis mellifera)
}

\author{
Silvio ERLER ${ }^{1}$, Robin F. A. Moritz ${ }^{1,2,3}$ \\ ${ }^{1}$ Institut für Biologie, Molekulare Ökologie, Martin-Luther-Universität Halle-Wittenberg, Hoher Weg 4, 06099, Halle \\ (Saale), Germany \\ ${ }^{2}$ Department of Zoology and Entomology, University of Pretoria, 0002, Pretoria, South Africa \\ ${ }^{3}$ German Centre for Integrative Biodiversity Research (iDiv) Halle-Jena-Leipzig, Deutscher Platz 5e, 04103, Leipzig, \\ Germany
}

Received 20 May 2015 - Revised 3 August 2015 - Accepted 8 October 2015

\begin{abstract}
Apitherapy promises cures for diseases in human folk medicine, but the effects of honeybee produced and foraged compounds on bee health are less known. Yet, hive products should chiefly facilitate medication and sanitation of the honeybees themselves rather than other organisms. We here review the impact of both self-produced gland secretions and foraged hive products (pharmacognosy) on colony health. Although foraged plant-derived compounds vary highly in antibiotic activity depending on the floral and regional origins, secondary plant metabolites in honey, pollen and propolis are important for the antibiotic activity against pathogens and parasites. However, specific bee health-enhancing activities of bee products should clearly be distinguished from the effects of an intact nutrition ensuring the basic immune competence of bees. Further unravelling the interactions among groups of active substances or individual compounds used in concert with specific behavioural adaptations will deepen our understanding of the natural potential of honeybees to maintain colony health.
\end{abstract}

honey / propolis / pollen / bee bread / royal jelly / antimicrobial activity / self-medication / host-parasite interaction

\section{INTRODUCTION}

The colony-based life history and social organization of honeybees (Apis mellifera) make them ideal targets for any parasite or pathogen infection (Schmid-Hempel 1998). The high density of closely related individuals, the constant environmental conditions, and the rich stores of proteins and carbohydrates in the nest provide ideal conditions for enemies, ranging from large vertebrate predators down

Corresponding author: R. Moritz, robin.moritz@zoologie.uni-halle.de Handling Editor: Yves Le Conte to infectious viruses (Mutinelli 2011; SchmidHempel 1998). Hence, it is not surprising to see a suite of bacterial, viral, fungal and protozoan infections as well as various parasitic arthropod infestations that cause serious damage to both individual bees and the colony as a whole (Bailey and Ball 1991; Morse and Flottum 1997; Schmid-Hempel 1998). Indeed, some of these agents (e.g. Varroa destructor, Nosema sp. and viruses) are currently considered to be involved in recently discussed global colony losses (Cornman et al. 2012; Genersch et al. 2010; vanEngelsdorp et al. 2009).

Yet, in spite of these dramatic reports, honeybees are by no means defenceless against diseases and pests neither at the individual nor at the colony level (Evans and Spivak 2010). External 
individual defence mechanisms (e.g. the insect cuticle) and also social defence mechanisms (e.g. seclusion of the nest cavity) provide efficient lines of defence against parasites and pathogens. The release of the honeybee genome gave a valuable insight into the genomic background of individual immune defence (Honeybee Genome Sequencing Consortium 2006). We now know that the four major innate immune pathways (Toll, Imd, JNK, JAK/STAT) are involved in the innate immune response of honeybees upon infection and wounding. A broad molecular toolbox is used for most effective defence mechanisms including proteasome-dependent degradation, apoptosis, melanisation and antimicrobial effector proteins which reduce or eliminate pathogens. Yet, comparing the honeybee with other insects shows that the Apis innate immune system is based on a severely reduced number of immunity-related genes (Evans et al. 2006). This came as a surprise, given the excellent intra-colonial conditions for pathogens and the apparent need for control. However, colony immunity is governed not just by individual immune competence but also by external immune defence (Otti et al. 2014). Mechanisms at the colony level have been shown to be equally important, and the reduction of immune genes may be more than compensated for by well-developed behavioural defence mechanisms, 'social' or 'collective immunity' (Cotter and Kilner 2010; Cremer et al. 2007).

Social immunity summarizes all antiparasitic colony-level mechanisms, not just reducing any parasite intake into the colony but also reducing the spread, and transmission between individuals and colonies (Cremer et al. 2007). This disease resistance resulting from social behaviour has been known since the ground-breaking work of Walter Rothenbuhler on hygienic behaviour (Rothenbuhler 1964; Rothenbuhler and Thompson 1956). Workers uncap cells with larvae infected with Paenibacillus larvae and remove the infected individuals from the colony. Hygienic behaviour has therefore successfully been used in selective breeding in the control of various brood diseases (e.g. American foulbrood, chalk brood and Varroa mites) (Harbo and Harris 1999; Palacio et al. 2010; Rothenbuhler and Thompson 1956; Spivak and Gilliam 1998). As there are several recent reviews available on hygienic behaviour and the importance of grooming for social insect colony defence, we will not address this issue in any deeper detail and would like to direct the reader to the excellent reviews of Evans and Spivak (2010) and Wilson-Rich et al. (2009) and references therein.

We will focus this review on those behavioural defence mechanisms that result from the bees' exceptional capacity as generalist foragers of plant products. The co-evolution of floral plants and pollinators has driven plants to provide nectar and pollen in exchange for the pollination service. In order to be attractive to bees, the nectar provided in a flower should not be fermented nor should pollen be contaminated with fungal pathogens. Hence, plants need to provide pathogen-free food for the bees if co-evolution is going to be a success story. It is therefore not that surprising to see plants adding antibiotic secondary metabolites to the nectar that prevent bacterial fermentation. In general, plants themselves need protection against bacterial and fungal pathogens and suites of highly active antimicrobial and antifungal compounds are known and used in many medical treatments in human medicine. When bee pollinators (both social and solitary) collect pollen and nectar from plants, they will therefore not just forage for protein and carbohydrate; they will inevitably also forage associated secondary plant metabolites that will have immediate impact on the individual bee and the colony, enhancing colony health. By foraging to satisfy their basic nutritional demand, honeybees inevitably gather compounds as part of the nectar or pollen that may become relevant to fight pests and pathogens. However, there is a concise difference between the nutritional function and the health function. The nutritional value of the food relates to the amount of carbohydrates, proteins, and other essential compounds ensuring basic physiological functioning and can always be needed in the colony irrespective of its health status. Health-relevant compounds may not be needed immediately, and this generates a problem. Specific foraging for health may not be possible because plants producing a specific compound may not be flowering when needed to fight specific diseases. So storage of these compounds becomes an issue, and it is here where the 
honeybee excels. The huge difference between eusocial honeybees with perennial colonies and all other bee pollinators is the exceptional capacity of the honeybee colony to store foraged plant products over extended periods of time. It is the ability to store the huge variety of foraged antimicrobial substances that lends the honeybee colony an enormous advantage not just within the bee pollinators but also over many other social insects that require animal protein in their diet. The capacity to store food provides the honeybees with an opportunity to selectively choose among the variety of stored products in an adaptive way dependent on their own or the colony's health status.

Given the huge field of apitherapy and the arguably not always convincing use of bee products in human medicine, it is clearly overdue to study the effects of antibiotic plant secondary metabolites more widely in the context of honeybee health rather than human health (the latter reviewed in some older reviews by Crane 1975 and Ghisalberti 1979).

Bees use native or processed hive products in two alternative pharmacological ways defined as pharmacophagy and pharmacophory. Pharmacophagy relates to all defence mechanisms resulting from the direct consumption (e.g. honey, pollen, royal jelly) to decrease the disease or increase honeybee health whereas pharmacophory refers to the nonedible hive products (e.g. propolis, resin) (König 1988). In addition to foraged compounds, we will also highlight those honeybeeproduced compounds that are not related to the innate immune system but nevertheless are highly effective against pests and pathogens. This will particularly include the compounds secreted in the various glandular systems of honeybees. Hence, we will address the self-produced and foraged compounds in honeybee colonies and discuss the health-promoting activity of these products.

2. ANTIBIOTIC AND BEE HEALTHENHANCING ACTIVITIES OF SELFPRODUCED HIVE AND BEE PRODUCTS

The honeybees' glands and glandular tissues produce a broad variety of well-identified pheromones and other secretions typically composed of various volatile and nonvolatile compounds (Mizrahi and Lensky 1997). The secretions of the hypopharyngeal, mandibular, venom and wax glands have been identified to be most important regarding self-medication by selfproduced bee products. Substances secreted by these exocrine glands do not just comprise the whole range of nutritive primary elements, including carbohydrates, proteins and fatty acids, but also compounds with antimicrobial activity.

\subsection{Cuticular hydrocarbons}

Cuticular hydrocarbons covering the entire body of the honeybee primarily function as a barrier to prevent water loss (Figure 1). In addition, they also affect the absorption of chemicals from the environment, can serve as pheromones, and most important for honeybee health, form a most efficient obstacle against the attachment to or penetration of the insect cuticle by microorganisms (Blomquist and Jackson 1979; Lockey 1988). They form an oily layer on the cuticle, which is continuously renewed by glandular secretions and prevents fungi and bacteria from entering the bees' body (Blomquist et al. 1980; Koidsumi 1957; Gołębiowski et al. 2013). The cuticular hydrocarbon composition varies during individual development and is dependent on both the environment and the individual health status (Blomquist et al. 1980). The honeybees' cuticular wax layer mainly consists of hydrocarbons, mono- and polyester, free fatty acids and other polar substances (Blomquist et al. 1980). These cuticular hydrocarbons serve as a kind of 'body lotion' washing off any potentially intruding pathogen and are therefore most essential for individual bee health. In addition, compounds that are easily dissolved in the oily hydrocarbons can be transported across the body surface. These compounds include esters and fatty acids, many of which are known to have antibiotic activity. Hence, although cuticular hydrocarbons themselves have no direct antimicrobial or antifungal function, they are crucial for self-sanitation and may serve as a carrier substance for antibiotic compounds to be spread on the body surface, 


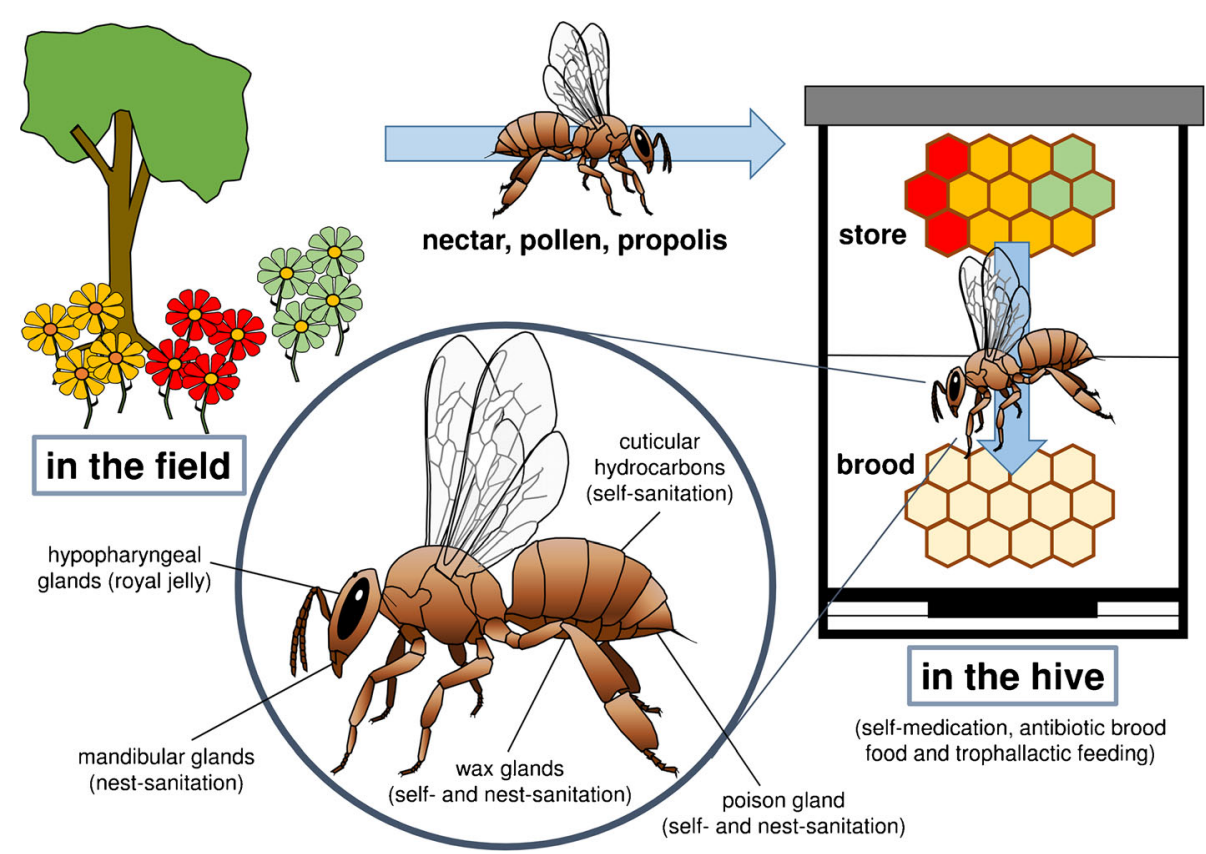

Figure 1. In-hive repertoire of foraged and self-produced agents used by honeybees not only for self- and nest sanitation but also for antibiotic feeding of brood and other nestmates. In the field: Secondary plant metabolites with antibiotic potential are inevitably foraged together with pollen and nectar. Propolis with highly antiviral and antibiotic compounds is collected by specific foragers for nest cavity sanitation. In the hive: Stored honey and bee bread can be selectively used for feeding diseased and healthy larvae and other nest members. On the bee: Glandular secretions with antibiotic activity can be used for individual and colony health.

which prevents adhesion of microorganisms or may be toxic to them.

\subsection{Beeswax}

The physiochemical and biological properties of beeswax have been comprehensively described in two monographs by the late Randall Hepburn (Hepburn 1986; Hepburn et al. 2014). Beeswax is secreted by the wax glands and is composed of a complex mix of alkanes, alkenes, hydrocarbons (14\%), free fatty acids (12\%), monoesters (35\%), diesters (14\%), hydroxymonoesters and some minor constituents (fatty alcohols and hydroxydiesters) (Hepburn et al. 2014; Mizrahi and Lensky 1997). The beeswax antibiotic activity is known for the fatty acids rather than the esters (Koidsumi 1957; Gołębiowski et al. 2013). Only very few studies address the biological activity of beeswax extracts against bee parasites and pathogens, but the natural comb has never been tested in situ in a biological setting. Wax extracts in acetone, ethanol and methanol repeatedly proved to have antimicrobial activity (Table I). In vitro assays verified the antibacterial activity against honeybee pathogens including Paenibacillus alvei and P. larvae (bacteria associated with American and European foulbrood) (Lavie 1960a), but also fungicide activity against Aspergillus flavus, Aspergillus fumigatus and Aspergillus niger-fungi associated with stone brood disease (Kacániová et al. 2012). Both assays used extracts of small pieces of comb heated $\left(80^{\circ} \mathrm{C}\right)$ or boiled for $1 \mathrm{~h}$ in the respective solvent. Any potential compounds in these extracts that might have caused the inhibitory activity had not been identified. Moreover, the wax had been extracted from old combs rather than wax from newly 
Table I. Effects of glandular secretions on bee parasites, pathogens and predators.

\begin{tabular}{|c|c|c|c|c|c|}
\hline Product & Application & $\begin{array}{l}\text { Parasite/ } \\
\text { pathogen/ } \\
\text { predator }\end{array}$ & Observation & $\begin{array}{l}\text { Technique/ } \\
\text { experiment }\end{array}$ & Reference \\
\hline \multirow[t]{2}{*}{ Wax } & Acetone extract & $\begin{array}{l}\text { P. alvei, } P \text {. } \\
\text { larvae }\end{array}$ & $\begin{array}{l}\text { Bacteria } \\
\text { growth } \\
\text { inhibition }\end{array}$ & In vitro assay & Lavie 1960a \\
\hline & $\begin{array}{l}\text { Ethanol and methanol } \\
\text { extracts }\end{array}$ & $\begin{array}{l}\text { A. flavus, } A \text {. } \\
\text { fumigatus, } \\
\text { A. niger }\end{array}$ & $\begin{array}{l}\text { Fungi growth } \\
\text { inhibition }\end{array}$ & In vitro assay & Kacániová et al. 2012 \\
\hline \multirow[t]{8}{*}{$\begin{array}{r}\text { Royal } \\
\text { jelly }\end{array}$} & Pure material & $\begin{array}{l}\text { E. faecalis, } P \text {. } \\
\text { larvae }\end{array}$ & $\begin{array}{l}\text { Bacteria } \\
\text { growth } \\
\text { inhibition }\end{array}$ & In vitro assay & $\begin{array}{l}\text { Hornitzky 1998; } \\
\text { Sauerwald et al. } \\
1998\end{array}$ \\
\hline & Acidic extract & P. larvae & $\begin{array}{l}\text { Bacteria } \\
\text { growth } \\
\text { inhibition }\end{array}$ & In vitro assay & $\begin{array}{l}\text { Bachanová et al. } \\
2002\end{array}$ \\
\hline & Aqueous-ethanol extract & P. larvae & $\begin{array}{l}\text { Bacteria } \\
\text { growth } \\
\text { inhibition }\end{array}$ & In vitro assay & $\begin{array}{l}\text { Crailsheim and } \\
\text { Riessberger-Gallé } \\
2001\end{array}$ \\
\hline & Ether extract & $\begin{array}{l}\text { P. alvei, } P \text {. } \\
\text { larvae }\end{array}$ & $\begin{array}{l}\text { Bacteria } \\
\text { growth } \\
\text { inhibition/ } \\
\text { delay }\end{array}$ & In vitro assay & Lavie $1960 \mathrm{~b}$ \\
\hline & $\begin{array}{l}\text { Major royal jelly protein } \\
2 \text {, defensin-1 }\end{array}$ & P. larvae & $\begin{array}{l}\text { Bacteria } \\
\text { growth } \\
\text { inhibition }\end{array}$ & In vitro assay & $\begin{array}{l}\text { Bachanová et al. } \\
\text { 2002; Bíliková et al. } \\
\text { 2001, } 2009\end{array}$ \\
\hline & Pure material & $\begin{array}{l}\text { A. apis, } A \text {. } \\
\text { niger }\end{array}$ & $\begin{array}{l}\text { Fungi growth } \\
\text { inhibition/ } \\
\text { weakening }\end{array}$ & In vitro assay & $\begin{array}{l}\text { Chu et al. 1992; } \\
\text { Sauerwald et al. } \\
1998\end{array}$ \\
\hline & $\begin{array}{l}\text { Crude extract and } \\
\text { fractions } \\
\text { (dichloromethane- } \\
\text { methanol) }\end{array}$ & V. destructor & $\begin{array}{l}\text { Deterrent } \\
\text { activity, } \\
\text { repellent } \\
\text { effect }\end{array}$ & $\begin{array}{l}\text { Arena } \\
\text { experiment }\end{array}$ & $\begin{array}{r}\text { Calderone et al. 2002; } \\
\text { Drijfhout et al. } 2005\end{array}$ \\
\hline & Octanoic acid & $V$. destructor & $\begin{array}{l}\text { Repellent } \\
\text { effect }\end{array}$ & $\begin{array}{l}\text { Arena } \\
\text { experiment, } \\
\text { bee colony }\end{array}$ & Nazzi et al. 2009 \\
\hline \multirow[t]{3}{*}{$\begin{array}{l}\text { Worker } \\
\text { jelly }\end{array}$} & Aqueous-ethanol extract & P. larvae & $\begin{array}{l}\text { Bacteria } \\
\text { growth } \\
\text { inhibition }\end{array}$ & In vitro assay & $\begin{array}{l}\text { Crailsheim and } \\
\text { Riessberger-Gallé } \\
2001\end{array}$ \\
\hline & Pure material & P. larvae & $\begin{array}{l}\text { Bacteria } \\
\text { growth } \\
\text { inhibition }\end{array}$ & In vitro assay & $\begin{array}{l}\text { Rose and Briggs } \\
1969\end{array}$ \\
\hline & $\begin{array}{l}\text { Crude extract } \\
\text { (dichloromethane- } \\
\text { methanol) }\end{array}$ & V. destructor & $\begin{array}{l}\text { Arrestment } \\
\text { response }\end{array}$ & $\begin{array}{l}\text { Arena } \\
\text { experiment }\end{array}$ & $\begin{array}{l}\text { Calderone and Lin } \\
2001\end{array}$ \\
\hline $\begin{array}{l}\text { Drone } \\
\text { jelly }\end{array}$ & $\begin{array}{l}\text { Crude extract and } \\
\text { fractions } \\
\text { (dichloromethane- } \\
\text { methanol) }\end{array}$ & $V$. destructor & $\begin{array}{c}\text { Arrestment } \\
\text { response }\end{array}$ & $\begin{array}{l}\text { Arena } \\
\text { experiment }\end{array}$ & $\begin{array}{l}\text { Calderone and Lin } \\
2001\end{array}$ \\
\hline
\end{tabular}

constructed virgin combs or freshly secreted wax scales. Hence, compounds transferred from stored honey, pollen, resin or bee larvae reared in these combs may also have contributed to the observed antibiotic effects, and not just wax itself. Nevertheless, given the antibiotic potential of 
many compounds in wax, it seems most likely that both the individual bees producing wax and the developing larvae may profit from the antibiotic potential in wax.

\subsection{Food jelly}

The nurse worker bees feed the larvae with a protein-rich secretion of the hypopharyngeal glands, termed royal jelly if fed to queen larvae, worker jelly if fed to worker larvae and drone jelly if fed to drone larvae. This food jelly is the exclusive diet of the adult queen but is also fed to all other adult members of the colony albeit as supplementary food. Food jelly is composed of water (60-70\%), proteins (12-15\%), sugar (10-16\%), lipids $(<10 \%)$ and traces of vitamins, salts and free amino acids. The majority of the protein fraction comprises the so-called major royal jelly proteins (for review, see Buttstedt et al. 2014).

Pure and even water-diluted royal and worker jelly has been shown to have antibiotic activity against bacteria (Enterococcus faecalis) and fungi (Ascosphaera apis and Aspergillus niger) (Table I). In addition, the antimicrobial effects of the various compounds in royal and worker jelly have been tested in vitro using acidic, aqueousethanol and ether extracts on $P$. alvei and P. larvae cultures (Table I). In general, royal jelly extracts had higher inhibitory effects than those of worker jelly (Crailsheim and Riessberger-Gallé 2001). Whereas the vegetative $P$. larvae cells are killed after 5 min of treatment with water-diluted royal jelly, the spores showed no reduced survival (Hornitzky 1998).

In vivo larval infection studies with the fungal pathogen Aspergillus fumigatus show a reduction of larval mortality with increasing royal jelly concentration (Foley et al. 2012). Whether this is due to malnutrition resulting from a lack of proteins in the diet or due to antifungal compounds in royal jelly needs to be determined.

Two isolated proteins (major royal jelly protein 2 and defensin-1) and the fatty acid 10-hydroxy-2decenoic acid are discussed as candidates of the antimicrobial activity of royal jelly (Bachanová et al. 2002; Bíliková et al. 2001, 2009; Chu et al. 1992; Hornitzky 1998). The antimicrobial activity of royal jelly is not just dose dependent but also varies significantly among honeybee colonies (Rose and Briggs 1969). Royal jelly from P. larvae-resistant colonies had much stronger antimicrobial activity than that from susceptible colonies (Rose and Briggs 1969). Honeybees may be able to adjust the quality of royal jelly in response to pathogen infections. Workers of $P$. larvae-infected colonies produce royal jelly with much higher amounts of antibacterial peptides (Bachanová et al. 2002). Most likely, the combination of high-quality proteinous food, enhancing bee health, with increasing antimicrobial activity offers a simple and effective method for reducing or eliminating intra-colony $P$. larvae titres. However, given the variability of royal jelly quality even within the same colony, there is certainly a wide open research field looking at the effects of the interactions between nutrition, pathogen and royal jelly quality. Nothing is known about seasonal, colony-specific or biogeographic effects relating to the numerous subspecies of Apis mellifera or the other Asian Apis species.

In addition to the antimicrobial and antifungal effects, royal jelly also interferes with parasites. Crude extracts (dichloromethane-methanol) and fractions of royal, worker and drone jelly used in arena experiments with $V$. destructor mites had repellent or arresting effects (Table I). Experiments using food jelly and $V$. destructor were conducted to understand why these mites prefer drone cells over queen cells to complete their reproductive cycle. A mix of 15 polar semiochemicals, originally characterized in native royal jelly fractions, showed to have a comparable deterrent activity against $V$. destructor (Drijfhout et al. 2005). Octanoic acid, as single repellent substance, is the first volatile substance being active against the mite under lab and field conditions (Nazzi et al. 2009). This fatty acid is as repellent as royal jelly itself and might be involved in the repellency of queen cells (Nazzi et al. 2009).

A single experiment has been conducted to unravel the self-medication potential of royal jelly by feeding different types of royal jelly (heterospecific feeding) to Chinese sacbrood virus (CSBV)-infected bee larvae. Heterospecific feeding, the feeding of bee larvae with royal jelly of non-species-specific origin, showed that feeding 
Apis cerana larvae with Apis mellifera royal jelly reduces mortality rates and therefore enhances resistance to Chinese sacbrood virus in comparison to feeding $A$. cerana larvae with $A$. cerana royal jelly. This effect was not observed for Apis mellifera larvae (Zhang et al. 2014). Heterospecific feeding might induce antiviral protein expression or royal jelly molecules can directly inhibit Chinese sacbrood viral replication in bee larvae (Zhang et al. 2014). Subsequent differential protein expression analysis found that proteins involved in stress response, phagocytosis, antioxidation and energy metabolism are candidates explaining the mortality-reducing activity of heterospecific feeding (Zhang et al. 2014).

\subsection{Bee venom}

Honeybee venom is a complex mix of proteins (phospholipase A, hyaluronidase), peptides (melittin, apamin), physiological active amines (histamine, dopamine), sugars, phospholipids and some volatile compounds (Mizrahi and Lensky 1997). The most active compound, with up to $50 \%$ of dry weight, is melittin. Its high antibiotic and biological activity has been studied for many decades in human apitherapy (Mizrahi and Lensky 1997; Ratcliffe et al. 2011). Only few studies analysed honeybee health-enhancing features of bee venom. Female honeybees smear venom proteins (melittin and apamin) on their body surface and on comb wax for self- and nest sanitation (Baracchi and Turillazzi 2010; Baracchi et al. 2011). However, given the high antibiotic potential, there is a surprising paucity of studies on the antibiotic activity of bee venom or venom proteins including potential interactions with other cuticular compounds.

\section{ANTIBIOTIC AND BEE HEALTH- ENHANCING ACTIVITIES OF FORAGED HIVE PRODUCTS}

Honeybees are vegetarians in a strictly vegan sense: nectar and pollen are the only protein and carbohydrate food sources. Clearly, the primary aim of foraging workers is to collect pollen, nectar and water for feeding the colony members. It is well understood how division of labour and worker specialization govern the allocation of foragers to the various tasks (Page 2013). In-hive workers further process the collected pollen and nectar to bee bread and honey. Both products can be stored for extended periods of time to bridge phases of dearth including winters and drought. However, pollen and nectar do not just comprise water, sugars and proteins. Trace elements, vitamins and particularly various secondary plant metabolites are included, which may have important effects on bee health and bee diseases (Brodschneider and Crailsheim 2010; Vaudo et al. 2015).

In addition, there are workers that specialize in the collection of plant resins. These resins are mixed with wax and other bee-derived substances to produce propolis (see Section 3.1) that is used to seal and protect potentially exposed regions of the nest cavity.

\subsection{Resin and propolis}

Resins are tree bud-, leaf- and woundexcreted sticky substances, which are foraged by the bees and termed propolis once used in the hive and mixed with pollen and wax by honeybees. The use of resins to improve and reshape the nest cavity is not unique to Apis mellifera. Stingless bees (Meliponini) also process resin either as cerumen (mixed with wax) and batumen or geopropolis (mixed with wax, mud, seeds, wood or vertebrate faeces) (Roubik 2006). The chemical composition (with more than 300 chemical compounds in complex and varied mixtures), floral origin and verification, folk medicine usage and general characteristics of propolis are comprehensively summarized in various reviews (Bankova et al. 2000, 2014; Burdock 1998; Ghisalberti 1979; Greenaway et al. 1990; Huang et al. 2014; Marcucci 1995; Mizrahi and Lensky 1997; Simone-Finstrom and Spivak 2010; Walker and Crane 1987). The composition even from the same plant species can vary markedly even depending on the sex in sexually dimorphic plants with two-times higher activity of female plant resin (Lokvam and Braddock 1999). 
Healthy worker bees treated with such extracts (ethanol and methanol) reduce their individual innate immunity and upregulate detoxification genes (Johnson et al. 2012; Simone et al. 2009). In addition, much lower microbe levels were detected in healthy colonies treated with different ethanolic propolis extracts (Simone et al. 2009). This effect was explained by inhibition due to direct contact of extracts and bacteria or by the volatile compounds released in the colony (Simone et al. 2009). Both studies were the first claiming the self-medication potential of foraged hive products.

Nearly all studies characterizing the antibiotic activity of resin and its products used extracts made with a huge variety of various solvents (acetone, acetonitrile, dimethylsulfoxide, ethanol, ethylacetate, hexane, methanol, petrol ether) or simply water (Table II). In vitro antibacterial activity is in a dose-dependent manner well confirmed for E. faecalis, $P$. alvei and $P$. larvae (associated with American and European foulbrood) using honeybee propolis (Table II). Climate, local environment and plant origin are the major drivers of varying antibiotic activity, with wet-tropical rainforest-type climate propolis showing the strongest activity (Seidel et al. 2008). The antibiotic activity seems to be very stable and the antibiotic effects of propolis showed no decline over time (Schmidt et al. 2014). Metabolomic studies on cottonwood and balsam poplar resin detected neither significant seasonal nor regional changes in major compound composition, but the different resin donor species varied in inhibition of P. larvae (Wilson et al. 2013). They showed that foraging honeybees make discrete choices among many closely related resinous plant species, depending on metabolite content and antimicrobial activity. Some studies showed that spraying or feeding ethanolic and aqueous propolis extracts can also act at the colony level. Treated colonies repeatedly have been shown to partially recover from the $P$. larvae infection. Typically treated colonies showed disease suppression and a reduction in diseased larvae compared to untreated control colonies (Kamel et al. 2013; Lindenfelser 1968; Mlagan and Sulimanovic 1982). Also the
P. larvae spore loads in honey were reduced after propolis extract treatment (Antúnez et al. 2008). These colony-level examples suggest that propolis compounds either directly inhibit the replication of vegetative $P$. larvae cells in the larval gut or stimulate the honeybee's immune system (Antúnez et al. 2008). Flavones/flavonols and flavanones/dihydroflavonols, the two major groups of propolis compounds, are most likely candidates to trigger the proposed mechanisms (Mihai et al. 2012).

A recent study tested several propolis samples, from 12 climatically diverse regions, against $P$. larvae and A. apis (chalk brood pathogen) and found that some samples did deviate from the generally high antibiotic activity observed against both pathogens. Four of the 12 samples were poor inhibitors of $P$. larvae growth, but good inhibitors of A. apis growth, suggesting that resin availability in these climatic regions was deficient in terms of providing broad-spectrum antibiotic activity (Wilson et al. 2015). Thus, regional differences in floral vegetation (resin donors) can very strongly determine antibiotic activity with highly variable therapeutic potential.

Propolis extracts inhibit the growth of not only A. apis but also other fungal pathogens including A. flavus, Aspergillus fumigatus and Aspergillus niger (Table II). Enhanced resin foraging was observed in chalk brood-infected and $V$. destructor-infested colonies (SimoneFinstrom and Spivak 2012; Popova et al. 2014). Increased amounts of resin reduced chalk brood infection intensities, however, without any knowledge of the exact causal mechanisms (SimoneFinstrom and Spivak 2012).

Resins have also been suggested to have an impact on Nosema infections. In cage experiments with Apis florea, ethanolic extracts of stingless bee cerumen (Trigona apicalis) reduced Nosema ceranae infection rates (Suwannapong et al. 2011). However, this study did not use $A$. florea-collected propolis, so the results on honeybees infected with $N$. ceranae have to be treated with caution in the context of self-medication of a honeybee colony. 
Table II. Effects of propolis on bee parasites, pathogens and predators.

\begin{tabular}{|c|c|c|c|c|}
\hline Application & $\begin{array}{l}\text { Parasite/ } \\
\text { pathogen/ } \\
\text { predator }\end{array}$ & Observation & $\begin{array}{l}\text { Technique/ } \\
\text { experiment }\end{array}$ & Reference \\
\hline Acetone extract & $\begin{array}{l}\text { E. faecalis, } P \text {. } \\
\text { alvei, } P \text {. } \\
\text { larvae }\end{array}$ & $\begin{array}{l}\text { Bacteria growth } \\
\text { inhibition }\end{array}$ & $\begin{array}{l}\text { In vitro } \\
\text { assay }\end{array}$ & Lokvam and Braddock 1999 \\
\hline $\begin{array}{l}\text { Dimethylsulfoxide } \\
\text { extract }\end{array}$ & E. faecalis & $\begin{array}{l}\text { Bacteria growth } \\
\text { inhibition }\end{array}$ & $\begin{array}{l}\text { In vitro } \\
\text { assay }\end{array}$ & Netíková et al. 2013 \\
\hline Ethanol extract & E. faecalis & $\begin{array}{l}\text { Bacteria growth } \\
\text { inhibition }\end{array}$ & $\begin{array}{l}\text { In vitro } \\
\text { assay }\end{array}$ & $\begin{array}{l}\text { Derevici et al. 1964; Kartal et al. } \\
\text { 2003; Koo et al. 2000; Kouidhi et } \\
\text { al. 2010; Mavri et al. 2012; Nieva } \\
\text { Moreno et al. 1999; Schmidt et al. } \\
\text { 2014; Seidel et al. 2008; } \\
\text { Stepanović et al. 2003; Uzel et al. } \\
2005\end{array}$ \\
\hline Methanol extract & $\begin{array}{l}\text { E. faecalis, } P \text {. } \\
\text { larvae }\end{array}$ & $\begin{array}{l}\text { Bacteria growth } \\
\text { inhibition }\end{array}$ & $\begin{array}{c}\text { In vitro } \\
\text { assay }\end{array}$ & $\begin{array}{l}\text { Boonsai et al. 2014; Erkmen and } \\
\text { Özcan 2008; Vardar-Ünlü et al. } \\
2008\end{array}$ \\
\hline Aqueous extract & P. alvei & $\begin{array}{l}\text { Bacteria growth } \\
\text { inhibition }\end{array}$ & $\begin{array}{l}\text { In vitro } \\
\text { assay }\end{array}$ & Lavie $1960 \mathrm{a}$ \\
\hline $\begin{array}{l}\text { Acetonitrile } \\
\text { extract }\end{array}$ & P. larvae & $\begin{array}{l}\text { Bacteria growth } \\
\text { inhibition }\end{array}$ & $\begin{array}{l}\text { In vitro } \\
\text { assay }\end{array}$ & Wilson et al. 2013 \\
\hline Ethanol extract & P. larvae & $\begin{array}{l}\text { Spore load } \\
\text { reduction in } \\
\text { honey }\end{array}$ & Bee colony & Antunez et al. 2008 \\
\hline Ethanol extract & P. larvae & $\begin{array}{l}\text { Bacteria growth } \\
\text { inhibition }\end{array}$ & $\begin{array}{l}\text { In vitro } \\
\text { assay }\end{array}$ & $\begin{array}{l}\text { Bastos et al. 2008; Bíliková et al. } \\
\text { 2013; Lindenfelser 1967; Mihai } \\
\text { et al. 2012; Özkırım et al. 2014; } \\
\text { Wilson et al. } 2015\end{array}$ \\
\hline $\begin{array}{l}\text { Ethanol extract, } \\
\text { aqueous extract }\end{array}$ & P. larvae & $\begin{array}{l}\text { Bacteria growth } \\
\text { inhibition }\end{array}$ & $\begin{array}{l}\text { In vitro } \\
\text { assay }\end{array}$ & $\begin{array}{l}\text { Lavie 1960a; Mlagan and } \\
\text { Sulimanovic } 1982\end{array}$ \\
\hline $\begin{array}{l}\text { Petrol ether, } \\
\text { ethylacetate } \\
\text { fraction }\end{array}$ & P. larvae & $\begin{array}{l}\text { Bacteria growth } \\
\text { inhibition }\end{array}$ & $\begin{array}{l}\text { In vitro } \\
\text { assay }\end{array}$ & Bíliková et al. 2013 \\
\hline Ethanol extract & $\begin{array}{l}\text { A. apis, } A \text {. } \\
\text { flavus, } A \text {. } \\
\text { fumigatus, } A \text {. } \\
\text { niger }\end{array}$ & $\begin{array}{l}\text { Fungi growth } \\
\text { inhibition }\end{array}$ & $\begin{array}{l}\text { In vitro } \\
\text { assay }\end{array}$ & $\begin{array}{l}\text { Falcão et al. 2014; Garedew et al. } \\
\text { 2004b; Ghaly et al. 1998; } \\
\text { Sahinler and Kurt 2004; } \\
\text { Samšiňáková et al. 1977; Wilson } \\
\text { et al. } 2015\end{array}$ \\
\hline $\begin{array}{l}\text { Ethanol and } \\
\text { methanol } \\
\text { extracts }\end{array}$ & $\begin{array}{l}\text { A. flavus, } A \text {. } \\
\text { fumigatus, } A \text {. } \\
\text { niger }\end{array}$ & $\begin{array}{l}\text { Fungi growth } \\
\text { inhibition }\end{array}$ & $\begin{array}{l}\text { In vitro } \\
\text { assay }\end{array}$ & Kacániová et al. 2012 \\
\hline $\begin{array}{l}\text { Dimethylsulfoxide } \\
\text { extract }\end{array}$ & A. fumigatus & $\begin{array}{l}\text { Fungi growth } \\
\text { inhibition }\end{array}$ & $\begin{array}{l}\text { In vitro } \\
\text { assay }\end{array}$ & Netíková et al. 2013 \\
\hline Ethanol extract & G. mellonella & $\begin{array}{l}\text { Reduced larval } \\
\text { growth and } \\
\text { survival, } \\
\text { metabolism } \\
\text { regulation }\end{array}$ & In vivo assay & $\begin{array}{l}\text { Eischen and Dietz 1987; Garedew } \\
\text { et al. 2004a; Johnson et al. } 1994\end{array}$ \\
\hline Ethanol extract & $V$. destructor & $\begin{array}{l}\text { Narcotic and } \\
\text { lethal effects, } \\
\text { metabolism } \\
\text { regulation }\end{array}$ & In vivo assay & $\begin{array}{l}\text { Damiani et al. 2010; Garedew et al. } \\
\text { 2002; Garedew et al. 2003a }\end{array}$ \\
\hline
\end{tabular}


Table II (continued)

\begin{tabular}{|c|c|c|c|c|}
\hline Application & $\begin{array}{l}\text { Parasite/ } \\
\text { pathogen/ } \\
\text { predator }\end{array}$ & Observation & $\begin{array}{l}\text { Technique/ } \\
\text { experiment }\end{array}$ & Reference \\
\hline Ethanol extract & V. destructor & $\begin{array}{l}\text { Reduced mature } \\
\text { female } \\
\text { production }\end{array}$ & Bee colony & Simone-Finstrom and Spivak 2010 \\
\hline Pure material & A. tumida & $\begin{array}{l}\text { Beetle } \\
\text { encapsulation }\end{array}$ & Bee colony & $\begin{array}{l}\text { Ellis et al. 2003; Neumann } \\
\text { et al. } 2001\end{array}$ \\
\hline Pure material & O. smaragdina & Repellent effect & $\begin{array}{l}\text { Open arena } \\
\text { experiment }\end{array}$ & $\begin{array}{l}\text { Duangphakdee } \\
\text { et al. } 2009\end{array}$ \\
\hline Pure material & $\begin{array}{l}\text { Ants, hunting } \\
\text { predators }\end{array}$ & Sticky barrier & Bee colony & Seeley et al. 1982 \\
\hline Pure material & $\begin{array}{l}\text { Dead } \\
\text { mammals, } \\
\text { large insects }\end{array}$ & Encapsulation & Bee colony & Visscher 1980 \\
\hline
\end{tabular}

Ethanolic extracts seem to act not only on pathogenic and parasitic microorganisms but also on larger enemies (Table II). Feeding propolis ethanolic extracts to wax moth (Galleria mellonella) larvae in in vivo assays reduced wax moth larval growth, survival and heat production with increasing propolis concentration (Eischen and Dietz 1987; Garedew et al. 2004a; Johnson et al. 1994). Topical application of propolis extracts on $V$. destructor in vivo in the honeybee colony resulted in narcotic and lethal effects on the mite, and again interfered negatively with the larval heat production (Damiani et al. 2010; Garedew et al. 2002, 2003a). Indeed, Simone-Finstrom and Spivak (2010) suggested a propolis treatment to reduce mature female mite production at the colony level.

Few studies show how native propolis is used in the context of colony health (Table II). Invading adults of the small hive beetle Aethina tumida were encapsulated in 'propolis prisons' to prevent establishment and spreading (Ellis et al. 2003; Neumann et al. 2001). Both studies highlighted significant differences in the observed encapsulation behaviour and effectiveness against the beetle, comparing European and South African cape honeybees. This mechanism is also used to isolate dead mammals or large insects within the colony (reviewed in Visscher 1980).

Raw honeybee propolis is further used to exclude honey- or brood-robbing ants, and other hunting predators from the nest (Table I). Hive entrances are glued with a propolis layer as a sticky barrier against small, crawling insects to protect bee colonies (Seeley et al. 1982). Such sticky barrier defence may also be a combination of mechanical and chemical defence. Open arena experiments showed a repellent effect of propolis against the weaver ant Oecophylla smaragdina. That effect was explained by the adhesive and viscous characteristics of the plant resins (Duangphakdee et al. 2009).

\subsection{Pollen and bee bread}

Pollen as collected by the foragers has on average about $35 \%$ proteinaceous content including about $50 \%$ free amino acids. The amounts of carbohydrate are highly variable, the lipid content is below $10 \%$ and vitamins, minerals and trace elements are present in quantities $<10 \%$ (Campos et al. 2008; Mizrahi and Lensky 1997). Proteincarbohydrate ratios and chemical composition depend not only on the floral origin but also on climatic and environmental conditions, plant age and nutrient status during pollen development and 
the water content of the pollen grain (Campos et al. 2008). The pollen foragers deposit the collected pollen pellets directly into the storage cell. The stored pollen is then transformed to bee bread by in-hive bees through lactic acid fermentation of pollen mixed with regurgitated nectar, honey and glandular secretions (Brodschneider and Crailsheim 2010). The nutritive value and physicochemical characteristics of fresh and processed pollen are not different from each other, suggesting that both are equally important for bee nutrition (Herbert and Shimanuki 1978). The pollen diet is not only important for the growing larvae, but also for the queen to ensure egg laying and the nurse bees to produce food jelly. Although other adult bees typically have a respiratory quotient close to 1 and primarily use carbohydrates to satisfy energy metabolism, they also need protein in their diet. This is of particular importance when it comes to immunity and fighting diseases. Alaux et al. (2010) studied the nutrigenomics and immuno-competence of caged honeybee workers and found increased glucose oxidase and phenoloxidase (PO) activity in bees fed with polyfloral compared to monofloral pollen. The pollen diet also increased vitellogenin and spätzle gene expression and the upregulation of TOR pathway and immunity genes, and enhanced antioxidative enzymes in honeybees compared to those kept on no-pollen diets (Alaux et al. 2011). Both studies highlight that pollen nutrition affects baseline immuno-competence and the diversity of floral resources have direct impact on bee health. Hence, constraints in nutrient diversity can result in honeybees that cannot establish an efficient immune defence and thus are a higher infection risk for the colony.

DeGrandi-Hoffmann et al. (2010) tested the impact of pollen nutrition on deformed wing virus (DWV) infection in cage experiments. They fed fresh pollen mixed with granulated sugar to honeybees infected with DWV. Pollen feeding reduced titres of DWV compared to controls (no protein at all). Whether this resulted from a direct antiviral potential of the pollen (DeGrandiHoffmann et al. 2010) or indirectly by enhancing the bees' immune system is not known. A recent colony-based experiment showed that feeding honeybee colonies on pollen of diverse botanical origin is correlated to low infection intensities with acute bee paralysis virus (ABPV), black queen cell virus (BQCV), DWV and sacbrood virus (SBV) (Antúnez et al. 2015). The observed antiviral activity of pollen was thought to be due to the presence of quercetin and other phenolic compounds (Antúnez et al. 2015). But again, the results can be explained by either malnutrition or a potential antiviral activity of specific pollen types. For more details on Varroa - and virus-infectiondriven immunity changes and trade-offs with (mal-)nutrition, please see the current review of DeGrandi-Hoffmann and Chen (2015).

Antibacterial and antifungal activities of pollen were assessed by testing the effects of solvent extracts in ethanol, methanol or water and waterethanol, on honeybee pathogenic bacteria (P. alvei, P. larvae) and fungi (A. flavus, Aspergillus fumigatus, Aspergillus niger) (Table III). Smith et al. (1949) were the first to show that aqueous pollen extracts inhibited $P$. larvae sporulation in a concentrationdependent manner. In a second experiment, they showed that this effect was linked to fractions more soluble in ether than in water, but did not identify specific antibiotic compounds in the extracts (Smith et al. 1949). Crailsheim and Riessberger-Gallé (2001) compared the antibacterial activity against $P$. larvae of pollen collected directly from flowers, pollen pellets collected from honeybee corbiculae and bee bread (waterethanol extracts). They consistently found concentration-dependent growth inhibition. Furthermore, the pollen-mediated growth inhibitory effect greatly increased the more the bees had processed the pollen. This was attributed to two nonexclusive mechanisms: (1) an enhanced activity resulting from substances added by the bees by regurgitating liquids from food glands or the honey stomach or (2) fermentation of pollen progressively releasing substances that were already in the pollen (Crailsheim and Riessberger-Gallé 2001).

Feeding P. larvae-infected colonies with pollen-water mixes reduced worker larvae mortality (Rinderer et al. 1974). More recent cage experiments showed a weak upregulation of antimicrobial effectors at the protein level in infected bees fed with a diet of polyfloral pollen and 
Table III. Effects of pollen and bee bread on bee parasites, pathogens and predators.

\begin{tabular}{|c|c|c|c|c|c|}
\hline Product & Application & $\begin{array}{l}\text { Parasite/ } \\
\text { pathogen/ } \\
\text { predator }\end{array}$ & Observation & $\begin{array}{l}\text { Technique/ } \\
\text { experiment }\end{array}$ & Reference \\
\hline \multirow[t]{8}{*}{ Pollen } & $\begin{array}{l}\text { Pure material } \\
\text { mixed with } \\
\text { sugar }\end{array}$ & DWV & $\begin{array}{l}\text { Reduced virus } \\
\text { concentration }\end{array}$ & $\begin{array}{l}\text { Cage } \\
\text { experiment }\end{array}$ & $\begin{array}{l}\text { DeGrandi-Hoffman } \\
\text { et al. } 2010\end{array}$ \\
\hline & Pure material & $\begin{array}{l}\text { ABPV, } \\
\text { BQCV, } \\
\text { DWV, SBV }\end{array}$ & $\begin{array}{l}\text { Reduced virus } \\
\text { concentration }\end{array}$ & Bee colony & Antúnez et al. 2015 \\
\hline & Ethanol extract & $\begin{array}{l}\text { P. alvei, } \\
\text { P. larvae }\end{array}$ & $\begin{array}{l}\text { Bacteria growth } \\
\text { inhibition }\end{array}$ & In vitro assay & Lavie 1960b \\
\hline & $\begin{array}{l}\text { Aqueous } \\
\text { extract }\end{array}$ & P. larvae & $\begin{array}{l}\text { Concentration- } \\
\text { dependent sporulation } \\
\text { increase and inhibition }\end{array}$ & In vitro assay & Smith et al. 1949 \\
\hline & $\begin{array}{l}\text { Aqueous- } \\
\text { ethanol } \\
\text { extract }\end{array}$ & P. larvae & $\begin{array}{l}\text { Bacteria growth } \\
\text { inhibition }\end{array}$ & In vitro assay & $\begin{array}{l}\text { Crailsheim and } \\
\text { Riessberger-Gallé } \\
2001\end{array}$ \\
\hline & $\begin{array}{l}\text { Ethanol and } \\
\text { methanol } \\
\text { extracts }\end{array}$ & $\begin{array}{l}\text { A. flavus, } \\
\text { A. fumigatus, } \\
\text { A. niger }\end{array}$ & $\begin{array}{l}\text { Fungi growth } \\
\text { inhibition }\end{array}$ & In vitro assay & $\begin{array}{l}\text { Kacániová } \\
\text { et al. } 2012\end{array}$ \\
\hline & $\begin{array}{l}\text { Pure material } \\
\text { mixed with } \\
\text { syrup }\end{array}$ & N. apis & $\begin{array}{c}\text { Increased spore } \\
\text { development }\end{array}$ & $\begin{array}{l}\text { Cage } \\
\text { experiment, } \\
\text { caged } \\
\text { colonies }\end{array}$ & $\begin{array}{l}\text { Beutler and Opfinger } \\
\text { 1950; Rinderer and } \\
\text { Elliot } 1977\end{array}$ \\
\hline & Pure material & N. ceranae & $\begin{array}{l}\text { Increased spore } \\
\text { development, with } \\
\text { lower pollen diversity }\end{array}$ & Bee colony & Invernizzi et al. 2011 \\
\hline \multirow[t]{3}{*}{$\begin{array}{l}\text { Bee } \\
\text { bread }\end{array}$} & $\begin{array}{l}\text { Aqueous- } \\
\text { ethanol } \\
\text { extract }\end{array}$ & P. larvae & $\begin{array}{l}\text { Bacteria growth } \\
\text { inhibition }\end{array}$ & In vitro assay & $\begin{array}{l}\text { Crailsheim and } \\
\text { Riessberger-Gallé } \\
2001\end{array}$ \\
\hline & $\begin{array}{l}\text { Pure material, } \\
\text { and mixed } \\
\text { with syrup }\end{array}$ & N. apis & $\begin{array}{c}\text { Increased spore } \\
\text { development }\end{array}$ & $\begin{array}{l}\text { Cage } \\
\text { experiment }\end{array}$ & $\begin{array}{l}\text { Beutler and Opfinger } \\
\text { 1950; Porrini et al. } \\
2011\end{array}$ \\
\hline & Pure material & N. ceranae & $\begin{array}{c}\text { Increased spore } \\
\text { development }\end{array}$ & $\begin{array}{l}\text { Cage } \\
\text { experiment }\end{array}$ & Basualdo et al. 2014 \\
\hline
\end{tabular}

honeydew honey (Höcherl et al. 2012). Again, either pollen could have facilitated an immune system upregulation in $P$. larvae-infected individuals or specific antibacterial components may be released by the partial digestion of pollen (Rinderer et al. 1974). Polyfloral pollen further increases survival rates for stone brood-infected bees, as shown with in vivo experiments using bee larvae, in comparison to monofloral pollen (Foley et al. 2012).

With the exception of a single study, spore development of Nosema apis and $N$. ceranae cannot be inhibited by feeding raw pollen or bee bread mixed with syrup (Table III). On the contrary, nutritional enrichment by protein feeding seems to be linked with an expansion of the bees' midgut, facilitating an increase in Nosema spore production (Beutler and Opfinger 1950; Rinderer and Elliot 1977). However, colonies fed with pollen from diverse botanical origins had lower levels of $N$. ceranae spores compared to colonies fed only with monofloral pollen (Invernizzi et al. 2011). Again, this result remains inconclusive regarding a 
differentiation between potential malnutrition and true self-medication.

Increased survival rates and therefore higher longevity may be a general effect of (polyfloral) pollen feeding in micro-parasite infection studies. Both $N$. apis and N. ceranae infection cage experiments showed comparable results on longevi-ty for pollen feeding per se and in particular for polyfloral pollen (Table III). Mostly, polyfloral pollen achieved better results in comparison with monofloral pollen.

Protein and amino acid quality and quantity are the main criteria regarding the healthpromoting activity of pollen. For example, a recent study showed that polyfloral pollen is not necessarily better than a monofloral pollen diet of high protein content (Di Pasquale et al. 2013). The nurse bees' physiology is expected to be affected by a qualitatively and quantitatively enhanced amino acid consumption. As a result, they might be able to produce a better quality food jelly that in turn might counteract the lifespan-reducing effect of Nosema infections in other bees. However, experi-ments in bee colonies and observation hives found exactly the opposite effects comparing both rearing methods. Supplementary pollen feeding increased bee longevity in observation hives independent of infection status, whereas no lifespan effect was observed for supplementary-fed infected bee colonies (Mattila and Otis 2006). When it comes to studying bee longevity, Nosema infection and pollen feeding, results from cage, observation hive and bee colony experiments showed opposing results and need to be evaluated with caution.

Varroa mite infestation studies using pollen and no-pollen feeding yielded similar gene expression patterns (increasing vitellogenin and immunity gene expression, upregulation of proteolysis, peptidase activity and carbohydrates metabolism) for bees with access to pollen independent of the infestation status. Comparing Varroainfested and not infested bees, mite infestation led to much lower gene expression levels and mostly downregulation of target genes (Alaux et al. 2011). The pollen feeding could not reverse the Varroa-induced negative effects on bee metabolism and immunity (Alaux et al. 2011).
Consequently, Varroa parasitism prevented bees from accessing the beneficial effects of pollen (Alaux et al. 2011). The colony's nutritional status affected not only the transcriptomic changes but also behavioural adaptations in individual bees. For example, Varroa jacobsoni -infested colonies increased the removal of infested brood when they had higher pollen stores (Janmaat and Winston 2000).

Honeybee larvae are typically fed pollen in the form of bee bread rather than of corbicular pollen (Brodschneider and Crailsheim 2010). Up to now, bee bread-induced beneficial bee health effects were only studied on Nosema-infected caged honeybees (Beutler and Opfinger 1950; Basualdo et al. 2014; Porrini et al. 2011). Feeding N. apis - and N. ceranae-infected worker bees bee bread mixed with sugar syrup or as raw material leads to increased longevity as already known for pollen. On the physiological level, $N$. ceranae-infected bees increase their haemolymph protein titre if fed with bee bread which may help them to tolerate the parasite infection (Basualdo et al. 2014). Regarding pollen as a foraged and stored item with a potential importance for colony health, the interpretation of the empirical data remains ambiguous because of the obvious role of pollen as a food source. Unless it is possible to separate food quality from direct medicinal effects of specific compounds, it will be difficult at best to dissect the effects of potential malnutrition and impaired immunity from those of a lack of pollen-derived antimicrobial compounds.

\subsection{Honey}

Honey is primarily composed of glucose and fructose as the main sugar compounds and water ( $\sim 20 \%)$. In addition, it also comprises, at a much lower level, di- and polysaccharides, minerals, amino acids and even some proteins (Crane 1975; Doner 1977). The high sugar concentration results in a strong osmotic pressure lethal for any microbe (except for symbiotic lactic acid bacteria, Olofsson and Vásquez 2008). This is the primary reason why honeybees can prevent honey from fermenting. So why should we bother about any other antimicrobial effects of honey if the high 
sugar concentration does it all? Indeed there is every reason to also look at diluted honey. Although honey is stored with high sugar concentrations, it becomes diluted as soon as it is added to the larval food and hence it would be highly adaptive if it also had antimicrobial effects at lower concentrations where osmotic pressure alone is insufficient as an antimicrobial factor. Various antimicrobial compounds and chemical properties other than the high sugar concentration have been identified (Molan 1992a, b) including hydrogen peroxide produced by glucose oxidase, low $\mathrm{pH}$ (acidity), methylglyoxal, the antimicrobial peptide bee defensin-1, major royal jelly protein 1 and various phenolic compounds which are important for the antimicrobial potential of honey (Brudzynski and Sjaarda 2015; Dustmann 1979; Kwakman and Zaat 2012). In addition, many highly plant-specific secondary metabolites have been identified in honey.

Most studies used natural (unprocessed) honey that makes it often difficult to differentiate between the effects of osmosis and antibiotic compounds (Table IV). Two studies used solvent extract fractions (methanol-water and acetone) to study the antibacterial activity of honey on honeybee pathogens. This seems like an odd approach as clearly in the colony, compounds will only operate in a water solvent condition (Table IV). Except for the historical French studies of the 1950 s-1960s testing natural honey against P. alvei and P. larvae (Gonnet and Lavie 1960; Lavie 1960b; Verge 1951), mainly the European foulbrood-associated bacterial strain E. faecalis has been tested (Table IV). More recent studies addressed how the interactions among the various antimicrobial substances affect the antibacterial activity of honey, against American and European foulbrood bacteria. There were pronounced honey type-dependent and honey pathogen-specific interaction effects (Bobiș et al. 2011, 2013; Erler et al. 2014). For instance, black locust honey inhibited the growth of European foulbrood-specific and European foulbroodassociated bacteria much more effectively than sunflower honey, whereas sunflower honey inhibited the growth of $P$. larvae strains more strongly than black locust honey (Erler et al. 2014).
Secondary plant metabolites including alkaloids, phenolic acids (e.g. caffeic, $p$-coumaric, ellagic and gallic acid) and flavonoids (e.g. chrysin, galangin, pinocembrin, quercetin, kaempferol and tectochrysin) are prime candidates for causing the observed interaction specificity (Erler et al. 2014; Cushnie and Lamb 2005). In vitro assays using pure honey (Table IV) and distillate fractions (ObaseikiEbor et al. 1983) showed that these compounds also have antifungal activity against the stone brood pathogens Aspergillus flavus, and Aspergillus niger.

Several studies focusing on Nosema spp. (Table IV) addressed the antibiotic effect of honey by counting dormant spores (Gherman et al. 2014; Gregorc 1993; Pohorecka and Skubida 2004). Both, cage and colony experiments showed that such spores are still infectious after storage in honey (but see White 1919). The honeys' antifungal activity, as direct measurement of spore load reduction, lead to the assumption that honey may inhibit at some point the life cycle of $N$. apis and $N$. ceranae (Table IV). Nonetheless, honey consumption does not always improve bee health even when impairing parasite development. For example, honeydew honey fed to wintering honeybees did inhibit $N$. apis development; nevertheless, it also resulted in increased bee mortality (Gregorc 1993; Pohorecka and Skubida 2004). The nonfloral origin of honeydew honey may have lacked the health-enhancing substances present in floral nectar.

The pharmacophagic effect of stored honey was tested on $N$. apis and $N$. ceranae infection experiments. Malone et al. (2001) compared the effect of two different honeys (manuka and thyme honey) and found that this decreased the individual bees' $N$. apis spore load. However, the results were less conclusive since sugar syrup-fed bees had the highest longevity (Malone et al. 2001).

Also, Gherman et al. (2014) showed honey type-specific spore load reduction for $N$. ceranae. They suggested multiple nonexclusive mechanisms that might be important: The active compounds may (1) kill Nosema spores, (2) increase the activity of the 
Table IV. Effects of honey on bee parasites, pathogens and predators.

\begin{tabular}{|c|c|c|c|c|}
\hline Application & $\begin{array}{l}\text { Parasite/pathogen/ } \\
\text { predator }\end{array}$ & Observation & $\begin{array}{l}\text { Technique/ } \\
\text { experiment }\end{array}$ & Reference \\
\hline Pure material & $\begin{array}{l}\text { B. pumilus, } \\
\text { B. laterosporus, } \\
\text { M. plutonius, } \\
\text { P. alvei, P. larvae }\end{array}$ & $\begin{array}{l}\text { Bacteria } \\
\text { growth } \\
\text { inhibition }\end{array}$ & $\begin{array}{l}\text { In vitro } \\
\text { assay }\end{array}$ & $\begin{array}{l}\text { Bobiş et al. 2011, 2013; Erler et al. } \\
\text { 2014; Gonnet and Lavie 1960; } \\
\text { Lavie 1960b }\end{array}$ \\
\hline Pure material & E. faecalis & $\begin{array}{l}\text { Bacteria } \\
\text { growth } \\
\text { inhibition }\end{array}$ & $\begin{array}{l}\text { In vitro } \\
\text { assay }\end{array}$ & $\begin{array}{l}\text { Chan-Rodríguez et al. 2012; da Cruz } \\
\text { et al. 2014; Efem et al. 1992; Erler } \\
\text { et al. 2014; Gallardo-Chacón et al. } \\
\text { 2008; Islaa et al. 2011; Temaru et al. } \\
\text { 2007; Tenore et al. 2012; Ulusoy } \\
\text { et al. } 2010\end{array}$ \\
\hline $\begin{array}{l}\text { Methanol-water } \\
\text { extract }\end{array}$ & E. faecalis & $\begin{array}{l}\text { Bacteria } \\
\text { growth } \\
\text { inhibition }\end{array}$ & $\begin{array}{r}\text { In vitro } \\
\text { assay }\end{array}$ & Escuredo et al. 2012 \\
\hline Acetone extract & P. larvae & $\begin{array}{l}\text { Bacteria } \\
\text { growth } \\
\text { delay }\end{array}$ & $\begin{array}{r}\text { In vitro } \\
\text { assay }\end{array}$ & Lavie $1960 \mathrm{~b}$ \\
\hline Pure material & A. flavus, A. niger & $\begin{array}{l}\text { Fungi } \\
\text { growth } \\
\text { inhibition }\end{array}$ & $\begin{array}{r}\text { In vitro } \\
\text { assay }\end{array}$ & $\begin{array}{l}\text { Boukraâ et al. 2008; Chanchao } \\
\text { 2009a; Efem et al. 1992; Fahim } \\
\text { et al. 2014; Gulfraz et al. 2010; } \\
\text { Radwan et al. 1984; Tenore et al. } \\
\text { 2012; Wellford et al. } 1978\end{array}$ \\
\hline Distillate fractions & A. niger & $\begin{array}{l}\text { Fungi } \\
\text { growth } \\
\text { inhibition }\end{array}$ & $\begin{array}{l}\text { In vitro } \\
\text { assay }\end{array}$ & Obaseiki-Ebor et al. 1983 \\
\hline Pure material & N. apis & $\begin{array}{l}\text { Reduced } \\
\text { infectivity }\end{array}$ & $\begin{array}{l}\text { Cage } \\
\text { experiment }\end{array}$ & Malone et al. 2001 \\
\hline Pure material & N. apis & $\begin{array}{l}\text { Spore load } \\
\text { reduction }\end{array}$ & Bee colony & $\begin{array}{l}\text { Gregorc 1993; Pohorecka and } \\
\text { Skubida } 2004\end{array}$ \\
\hline Pure material & N. ceranae & $\begin{array}{l}\text { Spore load } \\
\text { reduction }\end{array}$ & $\begin{array}{l}\text { Cage } \\
\text { experiment }\end{array}$ & Gherman et al. 2014 \\
\hline
\end{tabular}

honeybee immune system to fight against microsporidian infections, or (3) inhibit the replication of vegetative forms of Nosema spp. Whatever the actual mechanisms, those specific honey types that resulted in a reduction of a $N$. ceranae spore load had also been selected in a choice assay by workers infected with $N$. ceranae but not by healthy bees, suggesting a self-medication potential of honey at the level of the individual bee (Gherman et al. 2014).

Nutrigenomic studies used methanol and ethylacetate extracts of honey to measure transcriptional changes in healthy bees (Johnson et al. 2012; Mao et al. 2011, 2013). As a common result, genes related to detoxification processes and innate immunity (antimicrobial peptide genes) were upregulated in groups of bees fed with these extracts. A single substance seemed to modulate the measured transcriptional changes. The phenolic acid $p$-coumaric acid, the monomer of sporopollenin (the major plant spore and pollen outer wall compound), was isolated from these extracts and shown to actively detoxify pesticides and to activate innate immune system gene expression (Mao et al. 2011, 2013). p-Coumaric acid can be detected in honey, pollen, beebread and propolis, but not in nectar. The combination of its nutraceutical and antibiotic activity raises the possibility that $p$-coumaric acid together with 
other honey compounds (nectar-derived flavonoids: pinobanksin, pinobanksin 5-methyl ether, pinocembrin) may well interact with additive or synergistic consequences for innate immunity and detoxification (Mao et al. 2013).

A second group of plant-derived products enhancing bee health are phytohormones. Abscisic acid, a phytohormone regulating physiological functions in plants, can be detected in nectar, honey and honeybees at all stages. This phytohormone enhances the immune response (cellular and humoral) and wound healing of individual worker honeybees and the colony (Negri et al. 2015). Phytohormones are a new group of candidate substances that may be used by honeybees for various medicinal purposes. Currently, we are only at the beginning of understanding the potential function of these phytohormones for honeybees and more studies are needed to evaluate their antibiotic potential.

\section{CONCLUSION}

Gland-produced and foraged products have a highly diverse specificity and efficacy on bee parasites and pathogens. Scientists have tried over decades to unravel the molecular mechanisms behind the antibiotic effects of these products against viruses, bacteria and fungi. However, with increasing availability of high-resolution analytical tools, the puzzle gets more and more complicated rather than disentangled. Hundreds to thousands of substances can be identified with everdecreasing detection limits. How do these compounds interact? Which of these compounds are the ones used by the honeybees when choosing between two types of honey? These remain difficult questions to answer in spite of modern analytical instrumentation.

Pharmacophagy and pharmacophory are widely known for self-produced gland products. In particular, the antimicrobial substances of royal jelly (10-hydroxy-2-decenoic acid, major royal jelly protein 2 and defensin-1) help the bees in fighting against brood diseases. Self-medication per se has not been proven for them as yet. Studies analysing seasonal and between-hive antibiotic variance in combination with disease-associated feeding behaviour are needed to fully substantiate the supposed pharmacophagic potential of food jelly. We can only speculate on the pharmacological potential of beeswax and bee venom as their antibiotic activity for honeybee pathogens remains largely unknown. The antibiotic origin of gland secretions is even more complex than venom proteins and peptides. Solitary bees use volatile acyclic terpenoids, lipids and fatty acid derivatives, released from the mandibular gland, for nest cell sanitation and as predator repellent (Cane et al. 1983; Cane 1986). These fungistatic and bacteriostatic substances are applied against Aspergillus niger and other microorganisms, and may also be distributed during self-grooming. The mixture of proteinous substances, lipids and acids has potentially additive antibiotic effects or acts selectively on species-specific diseases.

In stark contrast, the results of hundreds of studies deal with the pharmacological potential of foraged hive products. The in-hive pharmacy provides three major types of natural medicine (honey, pollen/bee bread and propolis) for selfmedication usage. Propolis, not consumable by bees, can only be seen as indirect hive medicine, but nonetheless harbours a very high pharmacophoric activity. Plant resins are widely used in bee societies as honeybees and other bees share a common spectrum of diseases and predators. Stingless bees' resinous products have known antifungal effects (Aspergillus niger) (Garedew et al. 2003b; Muli et al. 2008) and are highly effective when used to mummify A. tumida beetles by deposing resin on the body of the intruder (Greco et al. 2010; Halcroft et al. 2011). Comparative studies (single type resin vs. mixtures) revealed that single resins may have different effects, and mixtures are more effective indicating functional complementarity for repellent effects against predatory ants and A. tumida (Drescher et al. 2014). Resins of different plant species not only target different organisms; they also act synergistically (Drescher et al. 2014). Stingless bees combine the repellent effect against ants and the advantage of the sticky barrier against predatory insects (Duangphakdee et al. 2009; Schwarz 1948, reviewed in Roubik 2006). During an ant attack, they increase their resin intake to build barriers of resin droplets, effectively entangling ants (Leonhardt and Blüthgen 
2009), and emit 'glue', presumably resin, on the invading ants (Lehmberg et al. 2008). These examples show that honeybees and stingless bees use resinous hive products in a very broad but similar pharmacophoric way.

Plant secondary metabolites, including the groups of flavones/flavonols and flavanones/ dihydroflavonols among others, are the prime candidates for the overall observed very high bactericide and fungicide activities. Most of the studies describing the antibiotic activity of resin and propolis use organic solvent extracts; bees never will use or have access to these, as they only collect water. Consequently, the results obtained by studying propolis extracts, but also extracts of other bee and hive products, have to be viewed with caution as providing causal explanations for their activity.

Pollen and honey were shown to have the highest variability in their pharmacophagic activity for several Apis (Tables III and IV) and nonApis bee species (Boorn et al. 2010; Chanchao 2009b; Chan-Rodríguez et al. 2012; da Cruz et al. 2014; Kimoto-Nira and Amano 2008; Logan et al. 2005; Temaru et al. 2007; Vandenberg 1994). An outstanding nonpharmacophagic but defensive usage of stored honey was observed for the stingless bee Hypotrigona braunsi . Field observations described invasion of Hypotrigona colonies by the honey robber Lestrimellita cubiceps. As a defensive strategy, worker bees deposit honey in the colony entrance (Michener 1959; de PortugalAraújo 1958). This blockage prevented honey robbing and shows that pharmacophory not only exists for propolis but also for honey.

At least for honey, many factors are known to be related with its antibiotic activity (hydrogen peroxide, low $\mathrm{pH}$, methylglyoxal, etc.). Again, it is the secondary plant metabolites that are gaining more and more importance in studying pharmacophagy and self-medication for individual bees and the brood. Alkaloids, phenolic acids (e.g. caffeic, $p$-coumaric, ellagic and gallic acid) and flavonoids (e.g. chrysin, galangin, pinocembrin, quercetin, kaempferol and tectochrysin) are linked with decreased parasite and pathogen loads in infected individuals. Recent studies report the antimicrobial potential of alkaloids, terpenoids and iridoid glycosides against a gut disease (Crithidia bombi) of bumblebees (Baracchi et al. 2015; Manson et al. 2010; Richardson et al. 2015). Studies on secondary plant metabolites in nectar should be extended to all groups of bee diseases to better understand the pharmacophagic potential of highly diverse foraging sites shared by honey and bumblebees collecting nectar and pollen.

Whereas a general intact nutrition will be essential to operate the honeybee's innate immune and detoxification system, the specific glandular and foraged compounds may be of particular importance to prevent and fight specific infections. Future studies should not just single out specific substances for their antibiotic activity and effects on the bees' health. If we want to comprehensively understand self-medication in the honeybee, we must understand how the individual worker bee with its excellent recognition senses combines its behaviour with the potentially available compounds from its rich glandular system and those available in the hive and its environment to maximize its own health and that of the colony.

\section{ACKNOWLEDGMENTS}

We would like to thank Alexis Beaurepaire for the help with translations of the French literature and Robin M. Crewe and two reviewers for comments on the manuscript. Financial support was granted by the Federal Ministry of Food, Agriculture and Consumer Protection (Germany): FIT-BEE project (grant no. 51106.01-28-1-71.007-10 to R.F.A.M.) and the DFG (priority programme SPP 1399 to R.F.A.M., and ER 786/11 to S.E.).

Pharmacophagie et pharmacophore : mécanismes d'auto-médication et de prévention des maladies dans la colonie d'abeilles (Apis mellifera)

miel / propolis / pollen / pain d'abeille / gelée royale / activité antimicrobienne / interactions hôte-parasite

Pharmakophagie und Pharmakophore: Mechanismen der Selbstmedikation und Krankheitsvorbeugung in Bienenvölkern (Apis mellifera)

Honig / Propolis / Pollen / Bienenbrot/ Königinnenfuttersaft / antimikrobielle Aktivität / Selbstmedikation / Parasit-Wirt-Interaktion 


\section{REFERENCES}

Alaux, C., Ducloz, F., Crauser, D., Le Conte, Y. (2010) Diet effects on honeybee immunocompetence. Biol. Lett. 6, 562-565

Alaux, C., Dantec, C., Parrinello, H., Le Conte, Y. (2011) Nutrigenomics in honey bees: digital gene expression analysis of pollen's nutritive effects on healthy and varroa-parasitized bees. BMC Genomics 12, 496

Antúnez, K., Harriet, J., Gende, L., Maggi, M., Eguaras, M., Zunino, P. (2008) Efficacy of natural propolis extract in the control of American Foulbrood. Vet. Microbiol. 131, 324-331

Antúnez, K., Anido, M., Branchiccela, B., Harriet, J., Campa, J., Invernizzi, C., et al. (2015) Seasonal variation of honeybee pathogens and its association with pollen diversity in Uruguay. Microb. Ecol. 70, 522533

Bachanová, K., Klaudiny, J., Kopernický, J., Simúth, J. (2002) Identification of honeybee peptide active against Paenibacillus larvae larvae through bacterial growth-inhibition assay on polyacrylamide gel. Apidologie 33 , 259-269

Bailey, L., Ball, B.V. (1991) Honey Bee Pathology. Academic Press Ltd., London

Bankova, V.S., de Castro, S.L., Marcucci, M.C. (2000) Propolis: recent advances in chemistry and plant origin. Apidologie 31, 3-15

Bankova, V., Popova, M., Trusheva, B. (2014) Propolis volatile compounds: chemical diversity and biological activity: a review. Chem. Cent. J. 8, 28

Baracchi, D., Turillazzi, S. (2010) Differences in venom and cuticular peptides in individuals of Apis mellifera (Hymenoptera: Apidae) determined by MALDI-TOF MS. J. Insect Physiol. 56, 366-375

Baracchi, D., Francese, S., Turillazzi, S. (2011) Beyond the antipredatory defence: honey bee venom function as a component of social immunity. Toxicon 58, 550-557

Baracchi, D., Brown, M.J.F., Chittka, L. (2015) Behavioural evidence for self-medication in bumblebees? [v2; ref status: indexed, http://f1000r.es/5ep] F1000Research 4,73

Bastos, E.M., Simone, M., Jorge, D.M., Soares, A.E., Spivak, M. (2008) In vitro study of the antimicrobial activity of Brazilian propolis against Paenibacillus larvae. J. Invertebr. Pathol. 97, 273-281

Basualdo, M., Barragán, S., Antúnez, K. (2014) Bee bread increases honeybee haemolymph protein and promote better survival despite of causing higher Nosema ceranae abundance in honeybees. Environ. Microbiol. Rep. 6, 396-400

Beutler, R., Opfinger, E. (1950) Pollenernährung und Nosemabefall der Honigbiene (Apis mellifica). Z. Vergl. Physiol. 32, 383-421

Bíliková, K., Wu, G., Simúth, J. (2001) Isolation of a peptide fraction from honeybee royal jelly as a potential antifoulbrood factor. Apidologie 32, 275-283
Bíliková, K., Mirgorodskaya, E., Bukovská, G., Gobom, J., Lehrach, H., Simúth, J. (2009) Towards functional proteomics of minority component of honeybee royal jelly: the effect of post-translational modifications on the antimicrobial activity of apalbumin2. Proteomics 9, 2131-2138

Bíliková, K., Popova, M., Trusheva, B., Bankova, V. (2013) New anti-Paenibacillus larvae substances purified from propolis. Apidologie 44, 278-285

Blomquist, G.J., Jackson, L.L. (1979) Chemistry and biochemistry of insect waxes. Prog. Lipid Res. 17, 319345

Blomquist, G.J., Chu, A.J., Remaley, S. (1980) Biosynthesis of wax in the honeybee Apis mellifera L. Insect Biochem. 10, 313-321

Bobiș, O., Mărghitaș, L.A., Dezmirean, D.S., Chirilă, F., Moritz, R.F.A. (2011) Preliminary studies regarding antioxidant and antimicrobial capacity for different types of Romanian honeys. Bulletin UASVM Anim. Sci. Biotechnol. 68, 91-97

Bobiş, O., Mărghitaș, L.A., Dezmirean, D.S., Gherman, B., Chirilă, F. (2013) In vitro antibacterial activity of unifloral honey against honeybee pathogens Paenibacillus larvae and Escherichia coli. Lucrări Științifice-Seria Zootehnie 60, 139-144

Boonsai, P., Phuwapraisirisan, P., Chanchao, C. (2014) Antibacterial activity of a cardanol from Thai Apis mellifera propolis. Int. J. Med. Sci. 11, 327-336

Boorn, K.L., Khor, Y.Y., Sweetman, E., Tan, F., Heard, T.A., Hammer, K.A. (2010) Antimicrobial activity of honey from the stingless bee Trigona carbonaria determined by agar diffusion, agar dilution, broth microdilution and time-kill methodology. J. Appl. Microbiol. 108, 1534-1543

Boukraâ, L., Benbarek, H., Ahmed, M. (2008) Synergistic action of starch and honey against Aspergillus niger in correlation with Diastase Number. Mycoses 51, 520522

Brodschneider, R., Crailsheim, K. (2010) Nutrition and health in honey bees. Apidologie 41, 278-294

Brudzynski, K., Sjaarda, C. (2015) Honey glycoproteins containing antimicrobial peptides, jelleins of the major royal jelly protein 1 , are responsible for the cell wall lytic and bactericidal activities of honey. PLoS ONE 10, e0120238

Burdock, G.A. (1998) Review of the biological properties and toxicity of bee propolis (propolis). Food Chem. Toxicol. 36, 347-363

Buttstedt, A., Moritz, R.F.A., Erler, S. (2014) Origin and function of the major royal jelly proteins of the honeybee (Apis mellifera) as members of the yellow gene family. Biol. Rev. 89, 255-269

Calderone, N.W., Lin, S. (2001) Behavioural responses of Varroa destructor (Acari: Varroidae) to extracts of larvae, cocoons and brood food of worker and drone honey bees, Apis mellifera (Hymenoptera: Apidae). Physiol. Entomol. 26, 341-350

Calderone, N.W., Lin, S., Kuenen, L.P.S. (2002) Differential infestation of honey bee, Apis mellifera, worker 
and queen brood by the parasitic mite Varroa destructor. Apidologie 33, 389-398

Campos, M.G.R., Bogdanov, S., de Almeida-Muradian, L.B., Szczesna, T., Mancebo, Y., Frigerio, C., Ferreira, F. (2008) Pollen composition and standardisation of analytical methods. J. Apic. Res. 47, 156-163

Cane, J.H. (1986) Predator deterrence by mandibular gland secretions of bees (Hymenoptera: Apoidea). J. Chem. Ecol. 12, 1295-1309

Cane, J.H., Gerdin, S., Wife, G. (1983) Mandibular gland secretions of solitary bees (Hymenoptera: Apoidea): potential for nest cell disinfection. J. Kansas Entomol. Soc. 56, 199-204

Chanchao, C. (2009a) Properties and antimicrobial activity of Apis dorsata honey from Thailand. Pak. J. Med. Sci. 25, 313-318

Chanchao, C. (2009b) Antimicrobial activity by Trigona laeviceps (stingless bee) honey from Thailand. Pak. J. Med. Sci. 25, 364-369

Chan-Rodríguez, D., Ramón-Sierra, J., Lope-Ayora, J., Sauri-Duch, E., Cuevas-Glory, L., Ortiz-Vázquez, E. (2012) Antibacterial properties of honey produced by Melipona beecheii and Apis mellifera against foodborn microorganisms. Food Sci. Biotechnol. 21, 905-909

Chu, L.-K., Liu, T.M.-E., Ho, K.-K. (1992) Growth inhibition of Ascosphaera apis by royal jelly and 10hydroxy-2decenoic acid. B. I. Zool. Acad. Sinica 31, 73-79

Cornman, R.S., Tarpy, D.R., Chen, Y., Jeffreys, L., Lopez, D., Pettis, J.S., vanEngelsdorp, D., Evans, J.D. (2012) Pathogen webs in collapsing honey bee colonies. PLoS ONE 7, e43562

Cotter, S.C., Kilner, R.M. (2010) Personal immunity versus social immunity. Behav. Ecol. 21, 663-668

Crailsheim, K., Riessberger-Gallé, U. (2001) Honey bee age-dependent resistance against American foulbrood. Apidologie 32, 91-103

Crane, E. (1975) Honey: A Comprehensive Survey. Heinemann, London

Cremer, S., Armitage, S.A., Schmid-Hempel, P. (2007) Social immunity. Curr. Biol. 17, R693-R702

da Cruz, C.B.N., Pieri, F.A., Carvalho-Zilse, G.A., Orlandi, P.P., Nunes-Silva, C.G., Leomi, L. (2014) Antimicrobial activity of honeys from two stingless honeybee species and Apis mellifera (Hymenoptera: Apidae) against pathogenic microorganisms. Acta Amaz. 44, 287-290

Cushnie, T.P.T., Lamb, A.J. (2005) Antimicrobial activity of flavonoids. Int. J. Antimicrob. Agents 26, 343-356

Damiani, N., Fernández, N.J., Maldonado, L.M., Alvarez, A.R., Eguaras, M.J., Marcangeli, J.A. (2010) Bioactivity of propolis from different geographical origins on Varroa destructor (Acari: Varroidae). Parasitol. Res. 107, 31-37

DeGrandi-Hoffman, G., Chen, Y. (2015) Nutrition, immunity and viral infections in honey bees. Curr. Opin. Insect Sci. 10, 170-176
DeGrandi-Hoffman, G., Chen, Y., Huang, E., Huang, M.H. (2010) The effect of diet on protein concentration, hypopharyngeal gland development and virus load in worker honey bees (Apis mellifera L.). J. Insect Physiol. 56, 1184-1191

de Portugal-Araújo, V. (1958) A contribution to the bionomics of Lestrimelitta cubiceps (Hymenoptera, Apidae). J. Kans. Entomol. Soc. 31, 203211

Derevici, A., Popesco, A., Popesco, N. (1964) Recherches sur certaines propriétés biologiques de la propolis. Ann. Abeille 7, 191-200

Di Pasquale, G., Salignon, M., Le Conte, Y., Belzunces, L.P., Decourtye, A., Kretzschmar, A., Suchail, S., Brunet, J.-L., Alaux, C. (2013) Influence of pollen nutrition on honey bee health: do pollen quality and diversity matter? PLoS ONE 8, e 72016

Doner, L.W. (1977) The sugars of honey-a review. J. Sci. Food Agric. 28, 443-456

Drescher, N., Wallace, H.M., Katouli, M., Massaro, C.F., Leonhardt, S.D. (2014) Diversity matters: how bees benefit from different resin sources. Oecologia 176, 943-953

Drijfhout, F.P., Kochansky, J., Lin, S., Calderone, N.W. (2005) Components of honeybee royal jelly as deterrents of the parasitic Varroa mite, Varroa destructor. J. Chem. Ecol. 31, 1747-1764

Duangphakdee, O., Koeniger, N., Deowanish, S., Hepburn, H.R., Wongsiri, S. (2009) Ant repellent resins of honeybees and stingless bees. Insectes Soc. 56, 333-339

Dustmann, J.H. (1979) Antibacterial effect of honey. Apiacta 14, 7-11

Efem, S.E.E., Udoh, K.T., Iwara, C.I. (1992) The antimicrobial spectrum of honey and its clinical significance. Infection 20, 227-229

Eischen, F.A., Dietz, A. (1987) Growth and survival of Galleria mellonella (Lepidoptera: Pyralidae) larvae fed diets containing honey bee-collected plant resins. Ann. Entomol. Soc. Am. 80, 74-77

Ellis, J.D., Hepburn, H.R., Ellis, A.M., Elzen, P.J. (2003) Social encapsulation of the small hive beetle (Aethina tumida Murray) by European honeybees (Apis mellifera L.). Insectes Soc. 50, 286-291

Erkmen, O., Özcan, M.M. (2008) Antimicrobial effects of Turkish propolis, pollen, and laurel on spoilage and pathogenic food-related microorganisms. J. Med. Food. 11, 587-592

Erler, S., Denner, A., Bobiş, O., Forsgren, E., Moritz, R.F.A. (2014) Diversity of honey stores and their impact on pathogenic bacteria of the honeybee, Apis mellifera. Ecol. Evol. 4, 3960-3967

Escuredo, O., Silva, L.R., Valentão, P., Seijo, M.C., Andrade, P.B. (2012) Assessing Rubus honey value: Pollen and phenolic compounds content and antibacterial capacity. Food Chem. 130, 671-678

Evans, J.D., Spivak, M. (2010) Socialized medicine: individual and communal disease barriers in honey bees. J. Invertebr. Pathol. 103, S62-72 
Evans, J.D., Aronstein, K., Chen, Y.P., Hetru, C., Imler, J.L., et al. (2006) Immune pathways and defence mechanisms in honey bees Apis mellifera. Insect Mol. Biol. 15, 645-656

Fahim, H., Dasti, J.I., Ali, I., Ahmed, S., Nadeem, M. (2014) Physico-chemical analysis and antimicrobial potential of Apis dorsata, Apis mellifera and Ziziphus jujube honey samples from Pakistan. Asian Pac. J. Trop. Biomed. 4, 633-641

Falcão, S.I., Vale, N., Cos, P., Gomes, P., Freire, C., Maes, L., Vilas-Boas, M. (2014) In vitro evaluation of Portuguese propolis and floral sources for antiprotozoal, antibacterial and antifungal activity. Phytother. Res. 28, 437-443

Foley, K., Fazio, G., Jensen, A.B., Hughes, W.O.H. (2012) Nutritional limitation and resistance to opportunistic Aspergillus parasites in honey bee larvae. J. Invertebr. Pathol. 111, 68-73

Gallardo-Chacón, J.J., Caselles, M., Izquierdo, M., Rius, N. (2008) Inhibitory activity of monofloral and multifloral honeys against bacterial pathogens. J. Apic. Res. 47, 132-137

Garedew, A., Lamprecht, I., Schmolz, E., Schricker, B. (2002) The varroacidal action of propolis: a laboratory assay. Apidologie 33, 41-50

Garedew, A., Schmolz, E., Lamprecht, I. (2003a) Microcalorimetric and respirometric investigation of the effect of temperature on the antivarroa action of the natural bee product-propolis. Thermochim. Acta 399, 171180

Garedew, A., Schmolz, E., Lamprecht, I. (2003b) The antimicrobial activity of honey of the stingless bee Trigona spp. J. Apic. Sci. 47, 37-49

Garedew, A., Schmolz, E., Lamprecht, I. (2004a) Effect of the bee glue (propolis) on the calorimetrically measured metabolic rate and metamorphosis of the greater wax moth Galleria mellonella. Thermochim. Acta 413, 63-72

Garedew, A., Schmolz, E., Lamprecht, I. (2004b) Microbiological and calorimetric investigations on the antimicrobial actions of different propolis extracts: an in vitro approach. Thermochim. Acta 422, 115-124

Genersch, E., von der Ohe, W., Kaatz, H., Schroeder, A., Otten, C., et al. (2010) The German bee monitoring project: a long term study to understand periodically high winter losses of honey bee colonies. Apidologie 41, 332-352

Ghaly, M.F., Ezzat, S.M., Sarhan, M.M. (1998) Use of propolis and ultragriseofulvin to inhibit aflatoxigenic fungi. Folia Microbiol. 43, 156-160

Gherman, B.I., Denner, A., Bobiș, O., Dezmirean, D.S., Mărghitaş, L.A., Schlüns, H., Moritz, R.F.A., Erler, S. (2014) Pathogen-associated self-medication behavior in the honeybee Apis mellifera. Behav. Ecol. Sociobiol. 68, 1777-1784

Ghisalberti, E.L. (1979) Propolis: a review. Bee World 60 , 59-84
Gołębiowski, M., Cerkowniak, M., Boguś, M.I., Włóka, E., Dawgul, M., Kamysz, W., Stepnowski, P. (2013) Free fatty acids in the cuticular and internal lipids of Calliphora vomitoria and their antimicrobial activity. J. Insect Physiol. 59, 416-429

Gonnet, M., Lavie, P. (1960) Influence du chauffage sur le facteur antibiotique present dans la miels. Ann. Abeille 3, 349-364

Greco, M.K., Hoffmann, D., Dollin, A., Duncan, M., Spooner-Hart, R., Neumann, P. (2010) The alternative pharaoh approach: stingless bees mummify beetle parasites alive. Naturwissenschaften 97, 319-323

Greenaway, W., Scaysbrook, T., Whatley, F.R. (1990) The composition and plant origins of propolis: a report of work at Oxford. Bee World 71, 107-118

Gregorc, A. (1993) The effects of honeydew honey on honey bee colonies (Apis mellifera carnica) and development of nosema disease (nosemosis). In "Prvi Slovenski Veterinarski Kongres, 18-20 November 1993, Portoroz, Slovenia."

Gulfraz, M., Iftikhar, F., Raja, S., Asif, S., Mehmood, S., Anwar, Z., Kaukob, G. (2010) Quality assessment and antimicrobial activity of various honey types of Pakistan. Afr. J. Biotechnol. 9, 6902-6906

Halcroft, M., Spooner-Hart, M., Neumann, P. (2011) Behavioral defense strategies of the stingless bee, Austroplebeia australis, against the small hive beetle Aethina tumida. Insectes Soc. 58, 245-253

Harbo, J.R., Harris, J.W. (1999) Heritability in honey bees (Hymenoptera: Apidae) of characteristics associated with resistance to Varroa jacobsoni (Mesostigmata: Varroidae). J. Econ. Entomol. 92, 261-265

Hepburn, H.R. (1986) Honeybees and Wax. Springer, Heidelberg

Hepburn, H.R., Pirk, C.W.W., Duangphakdee, O. (2014) Honeybee Nests: Composition, Structure, Function. Springer, Heidelberg

Herbert, E.W., Shimanuki, H. (1978) Chemical composition and nutritive value of bee-collected and bee-stored pollen. Apidologie 9, 33-40

Höcherl, N., Siede, R., Illies, I., Gätschenberger, H., Tautz, J. (2012) Evaluation of the nutritive value of maize for honey bees. J. Insect Physiol. 58, 278-285

Honeybee Genome Sequencing Consortium (2006) Insights into social insects from the genome of the honeybee Apis mellifera. Nature 443, 931-949

Hornitzky, M.A.Z. (1998) The pathogenicity of Paenibacillus larvae subsp. larvae spores and vegetative cells to honey bee (Apis mellifera) colonies and their susceptibility to royal jelly. J. Apic. Res. 37, 267271

Huang, S., Zhang, C.-P., Wang, K., Li, G.Q., Hu, F.-L. (2014) Recent advances in the chemical composition of propolis. Molecules 19, 19610-19632

Invernizzi, C., Santos, E., García, E., Daners, G., Di Landro, R., Saadoun, A., Cabrera, C. (2011) Sanitary and nutritional characterization of honeybee colonies 
in Eucaliptus grandis plantations. Arch. Zootec. 60, 1303-1314

Isla, M.I., Craig, A., Ordoñez, R., Zampini, C., Sayago, J., Bedascarrasbure, E., Alvarez, A., Salomón, V., Maldonado, L. (2011) Physico chemical and bioactive properties of honeys from Northwestern Argentina. LWT-Food Sci. Technol. 44, 1922-1930

Janmaat, A.F., Winston, M.L. (2000) Removal of Varroa jacobsoni infested brood in honey bee colonies with differing pollen stores. Apidologie 31, 377-385

Johnson, K.S., Eischen, F.A., Giannasi, D.E. (1994) Chemical composition of North American bee propolis and biological activity towards larvae of greater wax moth (Lepidoptera: Pyralidae). J. Chem. Ecol. 20, 17831791

Johnson, R.M., Mao, W., Pollock, H.S., Niu, G., Schuler, M.A., Berenbaum, M.R. (2012) Ecologically appropriate xenobiotics induce cytochrome P450s in Apis mellifera. PLoS ONE 7, e31051

Kacániová, M., Vuković, N., Chlebo, R., Haščík, P., Rovná, K., Cubon, J., Dżugan, M., Pasternakiewicz, A. (2012) The antimicrobial activity of honey, bee pollen loads and beeswax from Slovakia. Arch. Biol. Sci. 64, 927934

Kamel, A.A., Moustafa, A.A., Nafea, E.A. (2013) Propolis as a natural antibiotic to control American foulbrood disease in honey bee colonies. Afr. J. Agric. Res. 8, 3047-3062

Kartal, M., Yildiz, S., Kaya, S., Kurucu, S., Topçu, G. (2003) Antimicrobial activity of propolis samples from two different regions of Anatolia. J. Ethnopharmacol. 86, 69-73

Kimoto-Nira, H., Amano, K. (2008) Antimicrobial activity of honey produced by stingless honey bees. J. Apic. Res. 47, 325-327

Koidsumi, K. (1957) Antifungal action of cuticular lipids in insects. J. Insect Physiol. 1, 40-51

König, B. (1988) The honeybee as pharmacophorus insect. Entomol. Gener. 14, 145-148

Koo, H., Gomes, B.P., Rosalen, P.L., Ambrosano, G.M., Park, Y.K., Cury, J.A. (2000) In vitro antimicrobial activity of propolis and Arnica montana against oral pathogens. Arch. Oral Biol. 45, $141-148$

Kouidhi, B., Zmantar, T., Bakhrouf, A. (2010) Anticariogenic and anti-biofilms activity of Tunisian propolis extract and its potential protective effect against cancer cells proliferation. Anaerobe 16, 566-571

Kwakman, P.H.S., Zaat, S.A.J. (2012) Antibacterial components of honey. IUBMB Life 64, 48-55

Lavie, P. (1960a) Les substances antibactériennes dans las colonie d'abeilles (Apis mellifica L.). Ann. Abeille 3, 103-183

Lavie, P. (1960b) Les substances antibactériennes dans las colonie d'abeilles (Apis mellifica L.). Ann. Abeille 3, 201-299
Lehmberg, L., Dworschak, K., Blüthgen, N. (2008) Defensive behavior and chemical deterrence against ants in the stingless bee genus Trigona (Apidae, Meliponini). J. Apic. Res. 47, 17-21

Leonhardt, S.D., Blüthgen, N. (2009) A sticky affair: resin collection by Bornean stingless bees. Biotropica 41, 730-736

Lindenfelser, L.A. (1967) Antimicrobial activity of propolis. Am. Bee J. 107 (90-92), 130-131

Lindenfelser, L.A. (1968) In vivo activity of propolis against Bacillus larvae. J. Invertebr. Pathol. 12, 129131

Lockey, K.H. (1988) Lipids of the insect cuticle: origin, composition and function. Comp. Biochem. Phys. B 89, 595-645

Logan, A., Ruiz-González, M.X., Brown, M.J.F. (2005) The impact of host starvation on parasite development and population dynamics in an intestinal trypanosome parasite of bumble bees. Parasitology 130, 637-642

Lokvam, J., Braddock, J.F. (1999) Anti-bacterial function in the sexually dimorphic pollinator rewards of Clusia grandiflora (Clusiaceae). Oecologia 119, 534-540

Malone, L.A., Gatehouse, H.S., Tregidga, E.L. (2001) Effects of time, temperature, and honey on Nosema apis (Microsporidia: Nosematidae), a parasite of the honeybee, Apis mellifera (Hymenoptera: Apidae). J. Invertebr. Pathol. 77, 258-268

Manson, J.S., Otterstatter, M.C., Thomson, J.D. (2010) Consumption of a nectar alkaloid reduces pathogen load in bumble bees. Oecologia 162, 81-89

Mao, W., Schuler, M.A., Berenbaum, M.R. (2011) CYP9Q-mediated detoxification of acaricides in the honey bee (Apis mellifera). Proc. Natl. Acad. Sci. USA 108, 12657-12662

Mao, W., Schuler, M.A., Berenbaum, M.R. (2013) Honey constituents up-regulate detoxification and immunity genes in the western honey bee Apis mellifera. Proc. Natl. Acad. Sci. USA 110, 8842-8846

Marcucci, M.C. (1995) Propolis: chemical composition, biological properties and therapeutic activity. Apidologie 26, 83-99

Mattila, H.R., Otis, G.W. (2006) Effects of pollen availability and Nosema infection during the spring on division of labor and survival of worker honey bees (Hymenoptera: Apidae). Environ. Entomol. 35, 708-717

Mavri, A., Abramovič, H., Polak, T., Bertoncelj, J., Jamnik, P., Možina, S.S., Jeršek, B. (2012) Chemical properties and antioxidant and antimicrobial activities of Slovenian propolis. Chem. Biodivers. 9, 1545-1558

Michener, C.D. (1959) Sibling species of Trigona from Angola (Hymenoptera, Apidae). Am. Mus. Novit. 1956, $1-5$

Mihai, C.M., Mărghitaş, L.A., Dezmirean, D.S., Chirilă, F., Moritz, R.F.A., Schlüns, H. (2012) Interactions among flavonoids of propolis affect antibacterial activity against the honeybee pathogen Paenibacillus larvae. J. Invertebr. Pathol. 110, 68-72 
Mizrahi, A., Lensky, Y. (1997) Bee products: Properties, Applications, and Apitherapy. Springer, New York, NY

Mlagan, V., Sulimanovic, D. (1982) Action of propolis solutions on Bacillus larvae. Apiacta 17, 16-20

Molan, P.C. (1992a) The antibacterial activity of honey - 1. The nature of the antibacterial activity. Bee World 73, 5-28

Molan, P.C. (1992b) The antibacterial activity of honey - 2 . Variation in the potency of the antibacterial activity. Bee World 73, 59-76

Morse, R.A., Flottum, K. (1997) Honey bee pests, predators and diseases. Northern Bee Books, Medina, $\mathrm{OH}$

Muli, E.M., Maingi, J.M., Macharia, J. (2008) Antimicrobial properties of propolis and honey from the Kenyan stingless bee, Dactylurina schimidti . Apiacta 43, 4961

Mutinelli, F. (2011) The spread of pathogens through trade in honey bees and their products (including queen bees and semen): overview and recent developments. Rev. sci. tech. Off. int. Epiz. 30, 257-271

Nazzi, F., Bortolomeazzi, R., Della Vedova, G., Del Piccolo, F., Annoscia, D., Milani, N. (2009) Octanoic acid confers to royal jelly varroa-repellent properties. Naturwissenschaften 96, 309-314

Negri, P., Maggi, M.D., Ramirez, L., De Feudis, L., Szwarski, N., Quintana, S., Eguaras, M.J., Lamattina, L. (2015) Abscisic acid enhances the immune response in Apis mellifera and contributes to the colony fitness. Apidologie 46, 542-557

Netíková, L., Bogusch, P., Heneberg, P. (2013) Czech ethanol-free propolis extract displays inhibitory activity against a broad spectrum of bacterial and fungal pathogens. J. Food Sci. 78, M1421-M1429

Neumann, P., Pirk, C.W.W., Hepburn, H.R., Solbrig, A.J., Ratnieks, F.L.W., Elzen, P.J., Baxter, J.R. (2001) Social encapsulation of beetle parasites by Cape honeybee colonies (Apis mellifera capensis Esch.). Naturwissenschaften 88, 214-216

Nieva Moreno, M.I., Isla, M.I., Cudmani, N.G., Vattuone, M.A., Sampietro, A.R. (1999) Screening of antibacterial activity of Amaicha del Valle (Tucumán, Argentina) propolis. J. Ethnopharmacol. 68, 97-102

Obaseiki-Ebor, E.E., Afonya, T.C.A., Onyekweli, A.O. (1983) Preliminary report on the antimicrobial activity of honey distillate. J. Pharm. Pharmacol. 35, 748-749

Olofsson, T.C., Vásquez, A. (2008) Detection and identification of a novel lactic acid bacterial flora within the honey stomach of the honeybee Apis mellifera. Curr. Microbiol. 57, 356-363

Otti, O., Tragust, S., Feldhaar, H. (2014) Unifying external and internal immune defences. Trends Ecol. Evol. 29, 625-634

Özkırım, A., Çelemli, Ö.G., Schiesser, A., Charistos, L., Hatjina, F. (2014) A comparison of the activities of Greek and Turkish propolis against Paenibacillus larvae. J. Apic. Res. 53, 528-536
Page Jr., R.E. (2013) The Spirit of the Hive. Harvard University Press, Cambridge

Palacio, M.A., Rodriguez, E., Goncalves, L., Bedascarrasbure, E., Spivak, M. (2010) Hygienic behaviors of honey bees in response to brood experimentally pin-killed or infected with Ascosphaera apis. Apidologie 41, 602-612

Pohorecka, K., Skubida, P. (2004) Healthfulness of honeybee colonies (Apis mellifera L.) wintering on the stores with addition of honeydew honey. Bull. Vet. Inst. Pulawy 48, 409-413

Popova, M., Reyes, M., Le Conte, Y., Bankova, V. (2014) Propolis chemical composition and honeybee resistance against Varroa destructor. Nat. Prod. Res. 28, 788-794

Porrini, M.P., Sarlo, E.G., Medici, S.K., Garrido, P.M., Porrini, D.P., Damiani, N., Eguaras, M.J. (2011) Nosema ceranae development in Apis mellifera: influence of diet and infective inoculum. J. Apic. Res. 50, 35-41

Radwan, S.S., El-Essawy, A.A., Sarhan, M.M. (1984) Experimental evidence for the occurrence in honey of specific substances active against microorganisms. Zentralbl. Mikrobiol. 139, 249-255

Ratcliffe, N.A., Mello, C.B., Garcia, E.S., Butt, T.M., Azambuja, P. (2011) Insect natural products and processes: new treatments for human disease. Insect Biochem. Mol. Biol. 41, 747-769

Richardson, L.L., Adler, L.S., Leonard, A.S., Andicoechea, J., Regan, K.H., Anthony, W.E., Manson, J.S., Irwin, R.E. (2015) Secondary metabolites in floral nectar reduce parasite infections in bumblebees. Proc. R. Soc. B 282, 20142471

Rinderer, T.E., Elliot, K.D. (1977) Worker honey bee response to infection with Nosema apis: influence of diet. J. Econ. Entomol. 70, 431-433

Rinderer, T.E., Rothenbuhler, W.C., Gochnauer, T.A. (1974) The influence of pollen on the susceptibility of honey-bee larvae to Bacillus larvae. J. Invertebr. Pathol. 23, 347-350

Rose, R.I., Briggs, J.D. (1969) Resistance to American foulbrood in honey bees IX. Effects of honey-bee larval food on the growth and viability of Bacillus larvae. J. Invertebr. Pathol. 13, 74-80

Rothenbuhler, W.C. (1964) Behaviour genetics of nest cleaning in honey bees. I. Responses of four inbred lines to disease-killed brood. Anim. Behav. 12, 578583

Rothenbuhler, W.C., Thompson, V.C. (1956) Resistance to American foul brood in honey bees: I. Differential survival of larvae of different genetic lines. J. Econ. Entomol. 49, 470-475

Roubik, D.W. (2006) Stingless bee nesting biology. Apidologie 37, 124-143

Sahinler, N., Kurt, S. (2004) A study on antifungal activity of formic acid and propolis extract against chalkbrood disease pathogen Ascosphera apis . J. Anim. Vet. Adv. 3, 554-556 
Samšiňáková, A., Kálalová, S., Haragsim, O. (1977) Effects of some antimycotics and disinfectants on the Ascosphaera apis Maassen fungus in vitro. J. Appl. Entomol. 84, 225-232

Sauerwald, N., Polster, J., Bengsch, E., Niessen, L., Vogel, R.F. (1998) Combined antibacterial and antifungal properties of water soluble fractions of royal jelly. Adv. Food Sci. 20, 46-52

Schmidt, E.M., Stock, D., Chada, F.J.G., Finger, D., Sawaya, A.C.H.F., et al. (2014) A comparison between characterization and biological properties of Brazilian fresh and aged propolis. BioMed Res. Int. 2014, 257617

Schmid-Hempel, P. (1998) Parasites in Social Insects. Princeton University Press, Princeton, NJ

Schwarz, H.F. (1948) Stingless bees (Meliponidae) of the western hemisphere. B. Am. Mus. Nat. Hist. 90, 1546

Seeley, T.D., Seeley, R.H., Akratanakul, P. (1982) Colony defense strategies of the honeybees in Thailand. Ecol. Monogr. 52, 43-63

Seidel, V., Peyfoon, E., Watson, D.G., Fearnley, J. (2008) Comparative study of the antibacterial activity of propolis from different geographical and climatic zones. Phytother. Res. 22, 1256-1263

Simone-Finstrom, M., Spivak, M. (2010) Propolis and bee health: the natural history and significance of resin use by honey bees. Apidologie 41, 295-311

Simone-Finstrom, M.D., Spivak, M. (2012) Increased resin collection after parasite challenge: a case of selfmedication in honey bees? PLoS ONE 7, e34601

Simone, M., Evans, J., Spivak, M. (2009) Resin collection and social immunity in honey bees. Evolution 63, 3016-3022

Smith, R.L., Beck, J.V., Anderson, E.J. (1949) The effect of pollen on the sporulation of Bacillus larvae (WHITE). J. Bacteriol. 57, 213-218

Spivak, M., Gilliam, M. (1998) Hygienic behaviour of honey bees and its application for control of brood diseases and Varroa. Part I. Hygienic behaviour and resistance to American foulbrood. Bee World 79 , 124 134

Stepanović, S., Antić, N., Dakić, I., Svabić-Vlahović, M. (2003) In vitro antimicrobial activity of propolis and synergism between propolis and antimicrobial drugs. Microbiol. Res. 158, 353-357

Suwannapong, G., Maksong, S., Benbow, M.E. (2011) Stingless bee propolis effects on experimental infection of Apis florea with Nosema ceranae. J. Agric. Sci. Technol. A 1, 818-825

Temaru, E., Shimura, S., Amano, K., Karasawa, T. (2007) Antibacterial activity of honey from stingless honeybees (Hymenoptera; Apidae; Meliponinae). Pol. J. Microbiol. 56, 281-285

Tenore, G.C., Ritieni, A., Campiglia, P., Novellino, E. (2012) Nutraceutical potential of monofloral honeys produced by the Sicilian black honeybees (Apis mellifera ssp. sicula). Food Chem. Toxicol. 50, 1955-1961

Ulusoy, E., Kolayli, S., Sarikaya, A.O. (2010) Antioxidant and antimicrobial activity of different floral origin honeys from Turkiye. J. Food Biochem. 34, 321-335

Uzel, A., Sorkun, K., Onçağ, O., Cogŭlu, D., Gençay, O., Salih, B. (2005) Chemical compositions and antimicrobial activities of four different Anatolian propolis samples. Microbiol. Res. 160, 189-195

Vandenberg, J.D. (1994) Chalkbrood susceptibility among larvae of the alfalfa leafcutting bee (Hymenoptera: Megachilidae) reared on different diets. J. Econ. Entomol. 87, 350-355

vanEngelsdorp, D., Evans, J.D., Saegerman, C., Mullin, C., Haubruge, E., et al. (2009) Colony collapse disorder: a descriptive study. PLoS ONE 4, e6481

Vardar-Ünlü, G., Silici, S., Ünlü, M. (2008) Composition and in vitro antimicrobial activity of Populus buds and poplar-type propolis. World J. Microbiol. Biotechnol. 24, 1011-1017

Vaudo, A.D., Tooker, J.F., Grozinger, C.M., Patch, H.M. (2015) Bee nutrition and floral resource restoration. Curr. Opin. Insect Sci. 10, 133-141

Verge, J. (1951) L'activité antibactérienne de la propolis, du miel et de la gelée royale. Apiculteur 95, 13-20

Visscher, P. (1980) Adaptations of honey bees (Apis mellifera) to problems of nest hygiene. Sociobiology 5, 249-260

Walker, P., Crane, E. (1987) Constituents of propolis. Apidologie 18, 327-334

Wellford, T.E.T., Eadie, T., Llewellyn, G.C. (1978) Evaluating the inhibitory action of honey on fungal growth, sporulation, and aflatoxin production. Z. Lebensm. Unters. Forsch. 166, 280-283

White, G.F. (1919) Nosema-disease. U.S. Dept. Agric. Bull. 780, 1-59

Wilson, M.B., Spivak, M., Hegeman, A.D., Rendahl, A., Cohen, J.D. (2013) Metabolomics reveals the origins of antimicrobial plant resins collected by honey bees. PLoS ONE 8, e 77512

Wilson, M.B., Brinkman, D., Spivak, M., Gardner, G., Cohen, J.D. (2015) Regional variation in composition and antimicrobial activity of US propolis against Paenibacillus larvae and Ascosphaera apis. J. Invertebr. Pathol. 124, 44-50

Wilson-Rich, N., Spivak, M., Fefferman, N.H., Starks, P.T. (2009) Genetic, individual, and group facilitation of disease resistance in insect societies. Annu. Rev. Entomol. 54, 405-423

Zhang, Y., Zhang, G., Huang, X., Han, R. (2014) Proteomic analysis of Apis cerana and Apis mellifera larvae fed with heterospecific royal jelly and by CSBV challenge. PLoS ONE 9, e102663 